IZA DP No. 4204

Childcare, Eldercare, and Labor Force Participation of Married Women in Urban China: 1982-2000

Margaret Maurer-Fazio

Rachel Connelly

Chen Lan

Lixin Tang

June 2009 


\title{
Childcare, Eldercare, and Labor Force Participation of Married Women in Urban China: 1982-2000
}

\author{
Margaret Maurer-Fazio \\ Bates College and IZA \\ Rachel Connelly \\ Bowdoin College and IZA \\ Chen Lan \\ Institute of Labor Studies, \\ Ministry of Human Resources and Social Security, China \\ Lixin Tang \\ Bates College
}

Discussion Paper No. 4204
June 2009

IZA

P.O. Box 7240

53072 Bonn

Germany

Phone: +49-228-3894-0

Fax: +49-228-3894-180

E-mail: iza@iza.org

\begin{abstract}
Any opinions expressed here are those of the author(s) and not those of IZA. Research published in this series may include views on policy, but the institute itself takes no institutional policy positions.

The Institute for the Study of Labor (IZA) in Bonn is a local and virtual international research center and a place of communication between science, politics and business. IZA is an independent nonprofit organization supported by Deutsche Post Foundation. The center is associated with the University of Bonn and offers a stimulating research environment through its international network, workshops and conferences, data service, project support, research visits and doctoral program. IZA engages in (i) original and internationally competitive research in all fields of labor economics, (ii) development of policy concepts, and (iii) dissemination of research results and concepts to the interested public.
\end{abstract}

IZA Discussion Papers often represent preliminary work and are circulated to encourage discussion. Citation of such a paper should account for its provisional character. A revised version may be available directly from the author. 


\title{
ABSTRACT
}

\section{Childcare, Eldercare, and Labor Force Participation of Married Women in Urban China: 1982-2000}

\begin{abstract}
We employ data from the three most recent Chinese population censuses to consider married, urban women's labor force participation decisions in the context of their families and their residential locations. We are particularly interested in how the presence in the household of preschool and school-age children and/or the elderly and disabled affects women's likelihood of engaging in work outside the home. We find that the presence of older people in the household (any parent or parent-in-law and any person aged 75 or older) significantly increases prime-age urban women's likelihood of participating in market work and that presence of pre-school age children significantly decreases it. The negative effect on women's labor force participation of having young children in the household (compared to no children in the household) is substantially larger in magnitude for married, migrant women than for married, non-migrant urban residents. This appears to be explained, in part, by the practice of married, female migrants leaving their children in the care of relatives in rural areas in order to facilitate their employment.
\end{abstract}

JEL Classification: J11, J12, J13, J16, J22, O15, P23, R23

Keywords: labor force participation, China, childcare, eldercare, migrants, population census, urban women

Corresponding author:

Margaret Maurer-Fazio

Department of Economics

Bates College

Lewiston, ME 04240

USA

E-mail: mmaurer@bates.edu

\footnotetext{
The authors would like to thank Randall Akee, Xiaoyuan Dong, R.G. (Bob) Gregory, Daniel Hamermesh, Joan Hermsen, Melanie Khamis, Doug Krupka, Erin Krupka, Xin Meng, Zara Siddique, Enid Schatz, Steven Stern, Konstantinos Tatsiramos, Lowell Taylor, and Zhong Zhao for valuable comments and suggestions. We also appreciate the many thoughtful comments and suggestions from seminar participants at the School of Labor and Human Resources of Renmin University and the Economics Program of the Research School of Social Sciences at Australia National University. Margaret Maurer-Fazio gratefully acknowledges the financial support provided by IZA that allowed her to work on this paper while visiting IZA in the fall of 2008. Rachel Connelly and Margaret Maurer-Fazio also gratefully acknowledge financial support for this project from the Bates, Bowdoin, and Colby Colleges' Mellon Collaborative Faculty Development Fund.
} 


\section{Childcare, Eldercare, and Labor Force Participation of Married Women in Urban China: 1982--2000}

\section{Introduction}

In urban China's pre-reform labor system where the state guaranteed workers a job and expected all able-bodied individuals to work, prime-age women worked. In 1982, the labor force participation rate of prime-age, urban, married women, that is, married women living in urban areas between the ages of 25 and 50, was 86.7 percent. ${ }^{1}$ (See Figure 1 for the age-labor force participation profile.) The rate was so high that few researchers have invested time in considering who was out of the labor force. It seemed likely to be a mix of those with physical disabilities and the luck of the draw, that is, there would be a large stochastic element associated with who was in or out of the labor force. Also, why bother using empirical models of labor force participation decision making when the labor market was centrally planned? New entrants to the labor market were typically assigned to state-run and collective-run enterprises and remained there for life. However, it turns out that we should have been estimating labor force participation equations all along.

By the time of the Fifth National Population Census in 2000, the labor market in China had certainly changed. For the most part, the state had withdrawn from the business of assigning workers to work units, employment was no longer guaranteed for life, lay-offs had become commonplace and unemployment was rising. Especially hard hit were older, prime-age women who were encouraged/forced to retire even earlier than the official retirement age of $50 .^{2}$ By 2000 , the labor force participation

\footnotetext{
${ }^{1}$ Authors' calculations based on the 1 percent micro sample of the Third National Population Census of China.

${ }^{2}$ The retirement age of 50 applies to women who are "ordinary" workers. The retirement age for female cadres and those with advanced degrees is 55 . The retirement age for men is 60 .
} 
rate of prime-age, urban, married, non-migrant, women had fallen to 77.3 percent. The decline from the 1982 rates occurred almost entirely in the ten years between 1990 and 2000. ${ }^{3}$ Still, few labor economists were modeling women's labor force participation. (See Cai and Wang, 2005; Wang and Cai, 2004; and Yao and Tan, 2005 for notable exceptions.) While the situation had changed, it still did not seem as if the resulting lower labor force participation was a "choice" made by urban prime-age women. Most observers continued to assume that all married women who could find a job were employed, a sizable number were unemployed, and the rest were discouraged workers.

But there were signs that not all women were either working or looking for work. First, as Figure 1 demonstrates, the shape of the age-labor force participation profile has not changed substantially over the 18 year period, despite a serious restructuring of the economy and extensive changes in labor market institutions. The one notable change in the profiles revealed in Figure 1 is the later labor force entry of young people (age 20-25) in 1990 and 2000 relative to 1982. This is consistent with an increasing period of school attendance for many urban dwellers. The profile for 2000 also shows a slight decline in the labor force participation of 25 to 35 year olds which may be child-care related.

Figure 2 shows the activity status of the urban married women aged 25 to 50 who were not in the labor force, as a percent of total number of urban married women in this age category. Housekeeping, as an alternative to being in the labor force, is increasing over the three censuses and by 2000,16 percent of urban, non-migrant women report themselves as housekeeping. The percentage of women reporting themselves as retired or resigned also increased between 1990 and 2000. During this

\footnotetext{
${ }^{3}$ A similar steep decline in women's labor force participation occurred over the same period in the Central and East European economies undergoing transition from socialist to market economic systems. (See Pollert 2005.)
} 
period, income was rising rapidly among some urban households. These households were paying for expensive education for their children and buying new homes (and even second homes). Might they also invest in a stay-at-home mom to direct the educational activities of their child and to look after the growing numbers of aged? Maurer-Fazio, Hughes, and Zhang $(2005,2007)$ find both a decline in urban women's labor force participation (especially at older ages) and differentials in urban women's labor force participation by marital status. Married women exhibit lower rates of labor force participation than unmarried women. Yao and Tan (2005) find that women's labor force participation is inversely related to spousal income but that spousal income is insufficient to explain the steep decline of Chinese women's labor force participation.

Figure 2 also reminds us of the extraordinary change in the composition of the urban labor force between 1982 and 2000. The loosening of the strict migration controls of the planned-economy era led to large increases in the numbers and share of migrant workers in the urban work force. The flow of married, female migrants started much later than that of male and single female migrants but by 2000 , married, rural-migrant women constituted 11.6 percent of married women age 25-50 enumerated in the urban areas. ${ }^{4}$ In 1990, the comparable share was 2.4 percent. $^{5}$ Most of these married, female migrants come to the urban areas for employment opportunities. But some also migrate to accompany and support their husbands and children. The labor force participation rate of prime-age, rural migrants in urban

\footnotetext{
${ }^{4}$ Authors' calculations based on the 0.095 percent micro sample of the 2000 Population Census and the 1 percent micro sample of the 1990 Census.

${ }^{5}$ One needs to be a bit cautious here as the rules for enumerating migrants changed between the 1990 and 2000 Censuses. In 1990 migrants who had been in residence for one year or more were enumerated in the urban area. In 2000 there was more effort placed on enumerating the migrants in the urban areas and the residency length requirement was reduced to six months.
} 
China in 2000 was 62.3 percent, a full 15 percentage points less than urban, nonmigrant, married women.

As shown in Figure 2, married migrants are much more likely than nonmigrants to define their activity as housekeeping; in 2000, thirty-three percent of married migrants list themselves as housekeepers. The trend in labor force participation for married migrants is the opposite of that of non-migrants--in 2000, a greater percent of married migrants were in the labor force than in 1990 while the labor force participation rate of non-migrants declined over the same period.

Figure 3 provides a detailed look at the age-labor force participation profile for married rural migrants enumerated in urban China. The shape of the migrants' agelabor force participation profile differs dramatically from that of non-migrants. The decline in labor force participation for married migrants begins at age 20 and is quite rapid until age 26 . Thereafter, labor force participation rates remain fairly stable until age 42 when another rapid decline begins that lasts until age 50 .

In this paper, we explore the determinants of the labor force participation decisions of both rural migrant and non-migrant married women in urban China and investigate how these determinants have changed over the period made visible by the three censuses of 1982, 1990 and $2000 .^{6}$ We consider married women's labor force participation decisions primarily in the context of their families. We are particularly interested in how the presence in the household of preschool and school-age children and/or the elderly and the disabled affects women's likelihood of engaging in work outside the home. In addition, we are interesting in how China's substantial economic reform, changing demographic environment, and shifting expectations of gendered

\footnotetext{
${ }^{6}$ The rate of marriage in China is extremely high, so limiting our sample to married women aged 25-50 eliminates few prime-age women. In 2000, only 1.3 percent of women aged 30-34 and 0.5 percent aged 25-39 were single. Urban rates were somewhat higher but even in Beijing and Shanghai only 3.9 percent women aged 30-34 were single (Zhang and Gu 2007, 137-138).
} 
social roles have affected these determinants. In subsequent papers we will compare married, urban women's labor force participation with married, rural women's, consider difference across marital status, and compare urban, prime-age women's labor force participation rates to rates for older and younger cohorts. To answer these questions, we have pushed and pulled and tugged at the census data in order to be able to fully characterize the family circumstance of each prime-age, urban woman and to make our categories compatible across census years.

In Section II, we discuss a number of the factors thought to affect married women's participation in market work. We consider these factors in the context of China's changing economic and demographic environment. We then employ probit analysis to regress labor force participation on these factors and present our findings in Section III. We focus first on the experience of prime-age, urban, married nonmigrants in 2000. We then consider the change in the determinants of labor force participation over time by comparing the experience of urban non-migrant women in 2000 to that of their counterparts in 1982 and 1990. Finally, we investigate the determinants of married, migrant women's labor force participation and compare them to those for non-migrant urban residents. ${ }^{7}$

\section{II: Determinants of Married Women's Labor Force Participation Rates in Urban China}

In China, both the tradition of filial piety ${ }^{8}$ and the law ${ }^{9}$ oblige adult children to

\footnotetext{
${ }^{7}$ In this analysis we are excluding urban to urban migrants even though there are a substantial number of them. In our preliminary look at the data, the urban to migrants appear to consistently fall in between rural migrants and urban non-migrants in terms of the determinants of their labor force participation.

${ }^{8}$ Even though filial piety has been a very important element of Chinese society for thousands of years, it does not mean that care for the elderly comes about smoothly. In their study of the relationship between elderly parent health and the migration of adult children, Giles and Mu (2007) report that conflict among siblings over the care of the elderly was the third most important source of conflict in the 55 villages they surveyed. It was the first or second most important source of conflict in 11 of those villages. (See also Zhang 2005.)
} 
care for elderly parents and in fact, the majority of elderly Chinese (those age 65 and above) live with their children. ${ }^{10}$ Nationwide, the percentage of the elderly men and women living with their children remained almost constant between 1982 and 1990 at 68 percent and 74 percent, respectively, but declined to 60 percent and 69 percent by 2000 (Zeng and Wang, Table 2). The decline between 1990 and 2000 is due to a noticeable decrease in the proportion of the young elderly (aged 65-79) who co-reside with their children (Zeng and Wang, Tables $3 \& 4$ ).

There is a great deal of heterogeneity in the experience of aging in contemporary China and the housing reform and subsequent boom in the availability of new residential housing ${ }^{11}$ has enabled those with sufficient resources the possibility of independent living. Zhang (2008) documents a decline of family care and an increase in fee-based alternatives. ${ }^{12}$ She reports that some urban elders perceive separate living as yielding convenience, freedom, and better control over their lives. Pension availability has also contributed to an increase in independent living. ${ }^{13}$ Nonetheless, the predominance of family-based eldercare in China in the context of rapid population aging implies that families will soon face a profoundly increased burden of elder care. In 2000, 20.1 percent of Chinese households had at least one member aged 65 or above and the percentage of elderly in the population is

\footnotetext{
9 As Michael Palmer (1995) describes, both the Article 49 of the Constitution of 1982 and Article 15 of the 1980 Marriage Law require children who have come of age to support and assist their parents. Palmer also notes that Article 183 of the 1979 Criminal Law makes it an offense punishable for up to 5 years in prison for adult children to refuse to perform their duties to their parents.

${ }^{10}$ This phenomenon is not limited to the rural population; it also holds true for the urban population.

${ }^{11}$ The housing reforms, implemented nationally in the early 1990s, dramatically increased housing availability and ownership. Meng and Luo (2008) report that per capita residential floor space in urban China increased from 13.0 square meters in 1988 to 22.8 in 2002 and that residential housing sales increased over the same period from 255 million square meters to 2.2 billion square meters.

${ }^{12}$ Among the urban elderly, 9.8 percent of male and 15.1 percent of female octogenarians live in nursing homes (Zeng et al, 2002).

${ }^{13}$ There is a big gender difference in the availability of pension support amongst oldest old in urban areas. 70 percent of male octogenarians reported pension income as their main source of financial support in comparison to 26 percent of the females (Zeng et al, 2002).
} 
expected to rise from 7 percent ( 93 million) in 2000 to 15.7 percent ( 235 million) in 2030 and 22.7 percent (334 million) in 2050 (Zeng and Wang, 2003).

It is important to recognize, however, that co-residence of parents and/or parents-in-law with adult children does not necessarily imply the need for eldercare. Indeed, co-resident older family members may be net providers of care in the household. Co-resident grandmothers may well be looking after pre-school or schoolage children or may be doing the shopping, cooking and laundry that would facilitate younger women's employment outside the home. ${ }^{14}$ It is the very old who are the most likely to need care and given the short length of time between generations, the care of those over 80 will fall on adult children most of whom will be in their 50 s and $60 \mathrm{~s}^{15}$ Given China's early retirement age, most of urban women in their 50s are already retired.

Other demographic changes that have coincided with the economic reform period must be taken into consideration. The marked post-1970 decline in fertility implies that men and women now entering middle age have fewer siblings than previous generations and fewer siblings implies fewer family members who can help share in the provision of eldercare. If women drop out of the labor force to care for the elderly or disabled parents or parents-in-law and consequently give up pension entitlements, they may find themselves substantially disadvantaged as they age. However, while the burden of eldercare is likely to rise, the number of years spent in childbearing and childrearing has fallen.

\footnotetext{
${ }^{14}$ Nor, for that matter, does co-residence necessarily imply financial transfers from adult children to elderly parents. Cai, Giles, and Meng (2006) suggest to the contrary, that there is a good chance that net transfers are flowing from parents to children. In their study of how well adult children insure urban parents against low retirement incomes, they find that children living apart from parents are more likely to have four-year college educations and be employed and less likely to be ill or in school than those who live with parents.

${ }^{15}$ The prevalence of disability increases rapidly with age in the elderly Chinese population, especially for those aged 80 and above (Zeng and Wang, 2003).
} 
The rapid decline in the total fertility rate in urban China implies that current mothers and grandmothers are likely to spend fewer years in childcare than previous generations. However, mothers and grandmothers may devote substantially more time per child. It is possible, given the reported quality/quantity childcare tradeoffs of Chinese urban households, that time devoted to active childcare has increased.

Figure 4 shows the decline in the mean number of co-resident children across the three census years. Co-resident children are not a measure of total fertility. Many of the children of the older women (in the 25 to 50 age cohort) will be adults ${ }^{16}$ who may well be living in separate households.

Married, rural migrants and urban residents face very different environments with regard to childcare and differ quite substantially in their patterns of fertility. Both of these factors are likely to affect migrant women's participation in market work. Married migrants have more children than married urban dwellers, but as shown in Figure 5, they have fewer children than rural residents. In addition, many rural migrants leave their children in the rural area when they migrate. Figure 6 compares the numbers of surviving children to co-resident children for the rural migrants for 2000 and Figure 7 provides the same information for 1990. Comparing the two, we find that the number of children left in the rural area has increased between 1990 and 2000. This may be related to the increase in labor force participation of married, rural migrant women in 2000 compared to 1990.

For each married woman in the sample, we have created a set of indicator variables that characterize those with whom she co-resides, the age distribution of children in her household, and the standard demographics of education, age and ethnicity. When we first ran probit regressions on these household and individual

\footnotetext{
${ }^{16}$ We consider individuals age 18 and older to be adults.
} 
variables along with a set of dummies for the province of residence we found very large differences among the provinces in base labor force participation rates. (Results not reported.) In order to explore the nature of these differences, we created a set of contextual variables at the prefecture and provincial levels. These variables are intended to capture differences in labor market opportunities, the general health of the local economy, and differences in expectations about gender roles. The variables for provincial level per capita urban income and the growth rates of annual GDP over the previous five years were obtained from the statistical yearbooks and a compendium of GDP statistics released by the State Statistical Bureau. We calculated the prefectural variables from the census data itself - the unemployment rate by aggregating unemployment information for all prefectural residents, the infant sex ratio for all infants in the prefecture, the difference in sex specific rates of illiteracy for all prefectural residents, and the percent of Muslims in the prefecture's population. We created the latter three prefectural variables to get at differences in gender roles/ gender power across regions. As will be shown below, these contextual variables are significant predictors of prime-age, urban women's labor force participation. They do not explain all of the provincial differences but do reduce them substantially. More importantly, the demographic effects, discussed below, proved to be extremely robust with respect to the specification of the provincial and/or contextual variables.

In creating the co-residency and childcare variables, we seek to capture the impact that other family members may have on the time use and income demands of prime-age women. The presence of older co-residents could mean that the prime-age women have additional care-giving responsibilities which would be expected to lower 
their labor force participation rates. ${ }^{17}$ Alternatively, older household members might help out with household chores, and thus, facilitate the labor force participation of prime-age women. In addition, older household members might contribute income to the household, reducing the income motivation of prime-age women to participate in market work, or alternatively, require expensive medical care and the increase the incentive for prime-age women to contribute earnings to the household. Thus, we hypothesize that co-residency with older household members will affect women's labor force participation but are unable to predict the direction of the net effect. We expect, however, that the oldest co-residents will contribute less to the household and need more care, whether financial or physical. As such, we have included three separate co-residency indicators: co-residency with parents or parents-in-law, coresidency with a person aged 75 or above, and co-residency with a disabled person less than 65 years of age. We also control for the number of adults in the household.

In most countries, the labor force participation rates of married women with children are substantially less than the labor force participation of married women without children. The presence of young children in the household particularly reduces women's labor force participation rates. We thus characterize women's households by the age of the youngest children. We divide children into four age categories with differential time and income needs: preschoolers, aged 0 to 5, young school-age children, aged 6 to 12, who still need "watching" and delivering to and from school, older school-age children, aged 13 to 15 , who are still in compulsory education, and those aged 16 to 17 whose school fees, if they are in school, are substantially higher. As with co-residency with elders, the presence of children in the household may indicate increased demand for time, leading to reduced labor force

\footnotetext{
${ }^{17}$ Liu and Dong (2008) find that caring for parents does not affect the labor force participation or labor supply of married women in urban China but that caring for parents-in-law negatively affects both of these measures.
} 
participation or increased demand for money income to cover school and other children-centric expenditures leading to increased labor force participation. We divide women with no co-resident children into those under age 40 and those age 40 and above. The latter group is quite likely to have adult children. ${ }^{18}$ In our regression models we use the presence of a co-resident child aged 6 to 12 as the base case. Thus, the effects of having no co-resident children or younger or older co-resident children are presented as relative to the effects of having one's youngest child of elementary school age.

China's economic reforms and increased openness has widened the range of women's opportunities for paid employment as the economic structure shifted away from capital-intensive heavy industry towards labor-intensive light industry and commercial services. Economic growth and concomitant wage increases raise the opportunity cost of not working. However, the transition also created new obstacles for women's labor force participation. The state's retreat from its commitment to socialist ideology and enforcement of workplace protections for women coincided with a reemergence of traditional patriarchal values (Croll, 1995; Entwisle and Henderson, 2000). This retreat combined with growing pressure to reduce the size of the state-owned enterprise work force put pressure on women, especially older women, to leave the labor force and return to more subordinate roles. Increased workplace discipline and required effort levels also made it more difficult for some working women to cope with household responsibilities, thereby raising the costs of labor force participation, particularly for married women with young children.

At the household level, rising incomes of spouses and/or other household members can be viewed as an income effect for married women that would allow some

\footnotetext{
${ }^{18}$ Adult children may continue to live in the same households as their mothers. However, we count all members of the household of age 18 and older as adults.
} 
individuals to withdraw from the labor force when their spouses' earnings met household income goals. We included spouse's education as a proxy for spouse's income.

The recent tendency of high income, married women with young children to withdraw from the labor force may be dampened by China's birth planning policies, implemented first as the wan xi shao policy (later births, longer intervals, fewer children) in 1971 and followed by the even more stringent "one-child" policy of 1979, which drastically reduced total fertility rates and affected the value of time spent in home production. The vast majority of Chinese women continue to marry and to raise children but they have far fewer children and are finished with childbearing and childrearing at earlier ages than their mothers and grandmothers.

Education is increasingly rewarded in the Chinese workplace (Maurer-Fazio 1999; Zhang et. al. 2005). We, thus, expect to observe a positive relationship between level of education and labor force participation. In addition, the number of slots in higher education has increased, leading to an increased average level of education among prime-age women. Illiteracy may also take on a different meaning over the three censuses as the level of primary school initiation has continued to rise during this period. (Connelly and Zheng, 2007) The current pool of illiterate urban workers may be more self-selected towards mentally disabled persons.

The restructuring of the state-owned sector in the latter half of the 1990s led to the lay off of many millions of urban workers. Extended periods of lay off led, in turn, to withdrawal from the labor force of some of these workers. ${ }^{19}$ The layoffs appeared to fall disproportionately on women and older workers (Giles, Park, and Cai, 2006; Maurer-Fazio, 2006). It is difficult to tease out voluntary versus involuntary

\footnotetext{
${ }^{19}$ This phenomenon is commonly referred to as the discouraged worker effect.
} 
withdrawals from the labor market. It is our hope that comparing the determinants of labor force participation in these three periods (1982, which predates the majority of urban reforms, 1990, which is early on in the economic reform period when the market was still largely but not completely regulated and when rapid changes were leading to tremendous uncertainty about the future, and 2000, when a market-based labor market was much more firmly ensconced) will allow us to argue that not all of the decrease in urban women's labor force participation between the census periods was of an involuntary nature or at least that the involuntary component has not changed as much as one would have imagined.

Maurer-Fazio, Hughes, and Zhang $(2007,2009)$ explore whether China' reforms differentially affected the labor force participation of China's minority ethnic groups and the Han majority. They find that Muslim Hui women have significantly lower rates of participation than Han women. Given the high degree of assimilation of the Hui into Han society (relative to other ethnic minority groups), they argue that it would be difficult to attribute this finding to discrimination. They believe this effect to be a robust cultural or religious difference that surfaced with the relaxation of state control over individuals' lives. We explore this issue further by both controlling for those belonging to China's Muslim ethnic groups and controlling for the share of Muslims in the prefectural population.

Finally, we control for the location of residency, living in a city versus living in a town. The rate of change in the economy has been uneven with city labor markets emerging first. There are often very different regulations in towns versus cities, as the largest cities are trying to discourage in-migration while some town may welcome it. 


\section{Results}

We estimate probit regressions on women's labor force participation, controlling for the factors discussed above. The census data identify individuals as members of households which are classified as either family or collective. The data indicate the individual's relationship to the head of household and we are able to use that information to match the information of mothers to that of their co-resident children in at least 97.5 percent of all households in each of the three census years. We are unable to match mothers and children in collective households and in a small number of particular forms of multi-generation extended family households and we have dropped such cases from the analysis. As previously indicated, for each married woman in the sample, we have created a set of indicator variables that characterize those with whom she co-resides, the age distribution of children in the household, and the standard demographics of education, age and ethnicity and a number of contextual variables.

Defining urban and rural is not trivial in the Chinese censuses. The strategy we used differs by census year. In 2000, we used a variable from census questionnaire that designated an individual's location as city, town, or rural. We combined the city and town designations into an urban category. For 1990, we used a similar census variable. However, that variable was defined for each individual's location at the place where they usually lived five years before the census. For women who had not moved from that location by the time of the census, the majority of our sample, we once again added the city and town categories together to get urban. For those who had moved, we used the city, town, rural classification of non-movers at the new location to assign the rural urban status of the movers. We were unable to use a similar strategy for the 1982 sample and had to rely on administrative location codes 
for that year's data. Fortunately, the administrative county codes differentiate the districts administered by cities from those administered by rural counties and we were able to use this distinction to classify individuals' locations as rural or urban.

\section{III.1. Prime-Age, Married Women: Non-Migrant Urban Residents in 2000}

Table 1 focuses on the results obtained from our most recent data, that is, the data from the 2000 census. The sample includes married, non-migrant women between the ages of 25 and 50, living in family households in urban areas-the type of women one thinks of in the context of urban women's labor force participation. The mean of each independent variable is presented in the final column of the table. Marginal effects are presented instead of coefficients to help facilitate interpretation. Our non-migrant sample sizes are quite large so we have chosen a level of significance of 1 percent for our hypothesis testing.

We find that co-residency matters in ways that make sense but not necessarily in ways we expected. One of our main finding is that co-residency with older adults increases prime-age women's labor force participation rates. We had anticipated that the increasing life expectancy of the elderly might increase the burden of care on prime-age women. By 2000, the choice of the urban elderly to live or not live with adult children was much less constrained by a shortage of housing than in earlier years. Given the easing of housing constraints, we thought there would be an increasing tendency for the particularly frail elderly to opt to co-reside with adult

children. As such, we expected prime-age women to experience an increased burden of care provision, and thus, to be less likely to participate in market work. We find, however, that having a person aged 75 or above in residence increases the labor force participation rate of married, non-migrant, urban women by 2 percentage points and 
that having a co-residing parent or parent-in-law increases their participation by 4.6 percentage points. Living with a disabled person (younger than age 65) has a large negative effect on labor force participation--it reduces married women's participation by 7.5 percentage points. The difference in the effect of co-residency with a disabled person from that of a parent or parent-in-law strongly suggests that parents and parents-in-law are providing help in the household that facilitates women's employment.

Table 1 also reveals that the presence of pre-school children in the household reduces the labor force participation of their mothers. In 2000, mothers of children aged 0 to 5 were 4.2 percentage points less likely to be in the labor force than women with slightly older children. That this effect is typically larger in Western economies is less interesting than the fact that young children have any negative effect on labor force participation in urban China. The presence of children aged 13 to 15 , and those aged 16 to 17 have the same effect as the younger school-aged children on labor force participation. While the labor force participation rates of women who are 39 or younger with no children in the household are similar to those with school-age children, older women with no co-resident children are substantially less likely to be in the labor force. These older women with grown children may well be discouraged workers, but it is interesting to note that the women with children age 16 to 17 (many of whom are also over 40) are less discouraged. Tuition bills and other educational expenses may be acting as a strong motivation to stay in the labor market.

Education has a monotonically increasing effect on labor force participation. In comparison to women with junior high school educations, illiterate women are 2.6 percentage points less likely to be in the labor force while those with senior high 
school educations and post-secondary educations are 8.9 and 20.3 percentage points more likely, respectively.

Within the age range of 25-50, age increases participation slightly until age 39. Women aged 40 to 44 have participation rates equal to those of women aged 25-29 (having controlled for co-residence). After age 44 we observe a large and significant reduction in labor force participation. Women age 45-50 are 12.7 percentage points less likely to be in the labor force that those age 25-29. This result is consistent with the notion that women are being forced into early retirement. It is, however, also consistent with the hypothesis that some women of this age group are "voluntarily" withdrawing from the labor force to provide care for their grandchildren.

Spouse's education does not have a negative effect on women's labor force participation as might be expected if spouse's education was simply a proxy for spousal income. Women whose spouses have either primary education or postsecondary education are 2.2 and 4.6 percentage points more likely to be in the labor force, respectively, than those whose spouses have junior or senior middle school educations.

The Muslim effect on labor force participation, 5.2 percentage points, is negative and significant. The value falls nicely in between the -3.5 and -12.0 percentage point effects for Hui and Uygur women reported in Maurer-Fazio, Hughes, and Zhang (2009). ${ }^{20}$ Of the prefectural contextual variables, the Muslim share of the prefectural population is insignificant, while the unemployment rate and sex difference in rates of illiteracy have significant but quantitatively small effects. Similarly, the provincial-level variables of urban per capita income and the growth

\footnotetext{
${ }^{20}$ The Hui and Uygur ethnic groups constitute the vast majority of China's Muslim population.
} 
rate of GDP over the previous five years both affect women's labor force participation in very muted ways.

One possible criticism of the estimation procedure used to produce Table 1 is that it assumes that all co-residency variables are exogenously determined. An alternative approach would be to model the presence of the others in the household along with labor force participation. We believe that the strong familial pressure to have at least one child ${ }^{21}$ makes decision to have a child effectively a "non-decision" and thus exogenous to labor force participation. However, the timing of fertility is clearly a matter of choice as are the decisions of migrants on whether or not to bring their children with them to the urban areas and whether or not to send "home" children born in urban areas. Although there are strong normative and even legal requirements that adult children provide care for elderly parents, there is still an element of choice as to whether care provision involves co-residency. With the relaxation of housing constraints, greater pension availability, and increased income, relatively young elders are increasingly choosing to live on their own.

In order to explore the assumptions of exogeneity implicit in Table 1, we estimated three preliminary equations which predict the presence of the youngest children (most likely to be endogenous to today's labor force participation decision), the presence of parents and parents-in-laws and the presence of the elderly (aged 75 plus) in the household. For instruments we use the percent of households in the prefecture who have co-resident parents/in-laws and co-residents over age 70, a set of woman's age and her husband's age interactions and higher order terms, and a set of provincial dummies. $^{22}$

\footnotetext{
${ }^{21}$ This pressure is countered by China's strict birth control policies which prohibit most urban families from having more than one child.

${ }^{22}$ In the subsequent section that compares migrant women's labor force participation to that on nonmigrant women, we use a set of instruments that is almost identical. Instead of provincial dummies for
} 
In each case, the potential identifiers are significant with strong predictive powers. Overall, our predictive estimations explain 60 percent of the variance in the presence of parents or parents-in-laws, 26 percent of the variance in the presence of those 75 years of age or older, and 24 percent of the variance in presence of a youngest child age 0 to 5 .

Table 2 presents the resulting labor force participation model which includes these three predicted values instead of the observed values. The predicted values used are the probability of a positive outcome as estimated from the predicted coefficients of the first stage equation and the actual Xs. The marginal effects of the three predicted variables are consistent in sign and larger in magnitude than those on the observed values used in the single equation model. The marginal effects on other variables reported in Table 2 are completely consistent with the results reported in Table 1 with almost no changes in magnitudes. Thus, the basic findings reported above hold: co-residence with parents or parents-in-law and co-residence with any person aged 75 or above increased prime-age, urban, non-migrant, married women's labor force participation while the presence of a young child aged 0 to 5 decreases these same women's labor force participation.

\section{III.2. Are These Effects New? Comparing the Household and Personal Demographic Effects on Labor Force Participation over Time}

Table 3 reveals that the household and personal demographic effects discussed above are not new. They have, however, grown somewhat in magnitude over the time period under consideration, which seems in keeping with the notion that there is more choice in labor force participation than in the past. The results for 2000 are the same

the women's location at the time of census enumeration, we use a set of provincial dummies for the women's usual residential location five years before the census. 
as those presented in Table 1 but repeated here for ease of comparison. Co-residing with parents/parents-in-law has more of an impact on labor force participation in 2000 that it did in 1982 or 1990 but is significant and positive in all three years. It is interesting to note as well that the percent of married urban women living with parents or parents-in-law has remained constant at 18 or 19 percent for the last 18 years. Coresidence with the elderly did not seem to affect women's labor force participation in 1982 or 1990 but has a small positive effect in 2000. Living with a disabled person has become a less negative factor, moving from negative 11.9 percentage points to negative 7.5 percentage points. Thus, in each of these categories, the trend over time is toward increased labor force participation. That this result holds for the disabled as well as parents and the elderly suggests that the need for increased household income may be playing a role.

One of the most interesting findings of Table 3 is that having preschool children in the household reduces women's labor force participation in all three census years compared to women with young school-aged children. The magnitude of the effect is increases slightly from negative 2.6 to negative 4.2 percentage points. As we said before, even though the effects are small, that there are any negative effects of young children on labor force participation in urban China is news!

The effect of having no children at home and being over 40 has become increasingly negative, but even in 1982, married women in that category had a labor force participation rate 2.5 percentage points lower than women with school-age children. The direct effect of age on labor force participation at the oldest age cohort was also negative in 1982, in fact, the marginal effects are quite consistent across the three census years. This consistency confirms what we observed in the gross agelabor participation profiles presented in Figure 1. The decline in labor force 
participation of older, married women in urban areas can not be attributed exclusively to the structural changes in the economy brought on by China's economic reform.

The biggest change across the years is in the effect of education on labor force participation. In 1982, illiteracy had a large negative effect on prime age women's labor force participation while higher levels of education had a small positive effect. As we discussed above in 2000 , there is a small negative effect of illiteracy and a very large positive effect on post secondary education. This could reflect the changing rate of return to education, changes in the type of jobs available by education level, and the differential retirement age for women with higher education.

Being a member of one of China's Muslim ethnic groups had a negative 2 percentage point effect on women's labor force participation in 1982, a negative 3.8 percentage point effect in 1990 and a negative 5.2 percentage point effect in 2000. Again the changes are not large, the basic pattern is consistent across the time period, and yet, the increase in magnitude is consistent with others highlighted above that point to an increase in discretion regarding participation in market work for urban, prime-age, non-migrant, married women.

Again, controlling for the potential endogeneity does not substantially change our conclusions. As Table 4 reveals, the magnitude of the effect of co-residency with parents/in-laws quadruples in each year after taking into account the potential endogeneity. Co-residency with a person aged 75 or more goes from insignificant in 1982 and 1990 to a large positive effect in 2000. In 1982, the marginal effect of the predicted co-residence with youngest child age 0 to 5 is a positive 4.9 percentage points greater than that co-residence with youngest child age 6 to 12; in 1990, the marginal effect is negative 3.0 percentage points; and in 2000, the marginal effect is negative 5.8 percentage points. Thus, even controlling for the correlation in decision 
making between fertility timing and labor-force participation, the effect of having a young child has grown more negative over time.

\section{III.3. How Does Married Migrant's Labor Force Participation Differ from Urban Non-Migrants?}

In this section, we compare the determinants of labor force participation of the married, prime-age, rural migrants who were enumerated as living in urban areas to the married, prime-age, urban non-migrants highlighted thus far. Although the percent of rural migrants enumerated in the urban areas is much smaller in 1990, the total sample size available to us is large enough that we have a substantial number of married women to analyze. ${ }^{23}$

Table 5 repeats the urban non-migrant columns for 1990 and 2000 from Table 3 and adds the sample of married rural migrants. Although this table does not show substantial differences in the determinants of labor force participation (which is somewhat surprising given differences in the age-labor force participation profiles shown in Figures 1 and 3) some interesting differences do emerge. Co-residency with parents or parents-in law is somewhat less common among the migrants but still 13 percent of the migrants co-resided with parents or parents-in-laws in 1990 and 9 percent in 2000. Co-residency with parents or parents-in-law increases migrant women's labor force participation by 3.7 percentage points in 1990 and 7.2 percentage points in 2000. Another noteworthy difference between migrants and nonmigrants is that the negative effect of young children on the labor force participation is greater in magnitude for migrants than those of the non-migrant women. Migrant women with preschool children were 9 percentage points less likely to be in the labor

\footnotetext{
${ }^{23}$ We have omitted the group of women who are migrants but hold an urban hukou. They appear to be intermediaries between the two groups highlighted here. About 12 percent of urban women in 2000 can be categorized as "urban to urban migrants."
} 
force than migrant women with school-aged children in 1990 and 8 percentage points less likely in 2000. The age and education effects are quite similar for migrants and non-migrants with higher levels of education increasing labor force participation and the oldest age group having substantially lower levels of education.

Table 6 shows the same comparison as Table 5 but for models that include the predicted values of co-residence with parents/in-laws, co-residence with the elderly and co-residence with children age 0 to 5 . The results in Table 6 mirror Table 5 except that the estimated marginal effects of co-residence with parents or parents-inlaw and co-residence with young children increase substantially in magnitude. It appears that the marginal co-resident parent or parent-in-law of a migrant woman greatly facilitates her labor force participation. It also appears that many married migrants with co-resident children are not in the labor force in order to provide child care for very young children. Married migrants with no co-resident children constitute a much larger share of the population than in the non-migrant case: 9 percent in 1990 and 22 percent in 2000,. In 2000, these younger women with no children present are 14-17 percentage points more likely to be in the labor force than migrant women with young school-aged children (Tables $5 \& 6$ ). Also, child-free migrant women over age 40 do not reduce their labor force participation as while for non-migrant women, these older women's labor force participation is about 5 percentage points lower than women with young school-aged children (Tables $5 \& 6$ ).

We know from other sources that many migrant women leave their children in the rural areas. (Connelly, Roberts, and Zheng, 2008) This is also demonstrated strongly in Figure 6 for 2000 and somewhat less strongly in Figure 7 for 1990. We can also infer this from the means in Tables 5 and 6 where in 2000, 22 percent of the sample of younger married migrants had no children in the household while only 4 
percent of the urban residents sample were in the same category. However, for those migrants who do bring/keep their children with them, 67 percent of the rural migrant sample in 2000, it appears that many more of the rural migrant mothers "stay home" to provide child care and general household support for their working husbands and their children. ${ }^{24}$ One of the reasons that migrant women keep their children with them in urban areas may be a desire to improve their children's educational opportunities. A stay-at-home mother may be facilitating her children's schooling as well as her husband's employment. The opportunity cost of staying at home for migrants is not as high as it would be for urban non-migrants since migrant wages are much lower than those of non-migrants (Maurer Fazio and Dinh 2004, Frijters, Lee, and Meng, 2009). In addition, migrants in the city often lack the support of their extended families.

Opportunity cost may also explain why the negative effect of low education levels is larger in magnitude in 2000 for migrants than for non-migrants. Illiterate migrant women have a 7.0 percentage point lower labor force participation rate than those who graduated from junior middle school while for non-migrants there is 2.6 percentage point difference between illiterate women and those who graduated from junior middle school (Table 5). Migrant women who only attended primary school also have a significantly lower labor force participation rate in 2000 (than those who graduated from junior middle school) and they make up 34 percent of the sample. Among non-migrants, there is no difference in the labor force participation of those with only primary school education compared to those with a middle school education. While the lower opportunity cost of "keeping house" for migrant women with low educations is one explanation, it may also be the case that members of this

\footnotetext{
24 Tamara Jacka (2006) focuses on this group of women in her ethnography of migrant women in Beijing.
} 
group face more trouble in finding a job, and are more likely to become discouraged workers.

The differential in labor force participation rates by age is comparable for rural migrants and urban non-migrants. Rural migrants aged 45-50 are 13.7 percentage points less likely to be in the labor market compared with 25-29 year-old migrants in 2000, while the effect for non-migrants is also sizable at 12.7 percentage points. However, the decline in labor force participation begins sooner for migrants. Those aged 40-44 have a 5.5 percentage point decline in labor force participation compared to 25-29 year olds while there was no negative effect of being 40-45 for urban residents. Again, we need to question what these older rural migrants are doing in the urban area if they are not working. Given the younger age of marriage of rural women compared to urban women and younger age at first birth, the 40 year old plus rural women are much more likely to be grandmothers than the non-migrant urban women in the same age category. Thus, the older rural migrants who are not in the labor market may be in the urban area to care for their grandchildren facilitating the labor force participation of their daughters-in-law.

The negative effect on labor force participation of belonging to a Muslim minority disappears in the migrant sample while the provincial income effects are larger for the migrant group. This makes sense in that the migrants are selecting a destination while the urban non-migrants are simply affected by the labor market health of their home city.

\section{Conclusions}

In this paper, we have examined evidence of prime age women's labor force participation decisions over an 18-year time period that coincides with the period of 
rapid structural change in the urban Chinese labor market. We find evidence of increasing discretion in prime-aged women's labor force participation in urban China. Co-residency with older relatives does not appear to reduce prime-age married women's participation in market work, but rather to increase it. This employmentfacilitating effect of co-residency with elders is even larger for migrants than nonmigrants. Migrant women's participation in market work also appears to be hampered to a much greater extent by childcare concerns than that of urban non-residents. In 2000, migrant women with pre-school age children were 13.1 percentage points less likely to participate in market work than migrant women with young school aged children and 30.1 percentage points lower than married migrant women with no coresident children (Table 6). In contrast, urban women with young children were 5.8 percentage points less likely to be in the labor force compared with those women with young school-aged children and 7.3 percentage points less likely to be in the labor force than their childless counterparts. (Table 6, 2000 sample)

A comparison of the three census years for the non-migrants (Tables 3 and 4) shows us that since 1982, the presence of young children has had a negative effect on women's labor force participation. The negative effect of young children has grown over time as we expected, given both increased income and the greater degree of personal choice available to urban women in 2000 compared to 1982 and 1990.

Another large change from 1982 to 2000 has been a much expanded differential in labor force participation by education especially at the top of the education distribution. In 1982, women with post secondary education were 5.7 percentage points more likely to be in the labor force than those with middle school education while in 2000 the differential is 20.3 percentage points. (Table 4) 
Somewhat surprisingly, we do not see large changes between 1982 and 2000 in the differential in labor force participation by age. We had expected to see large declines in the labor force participation at the oldest age category in the most recent census, due to differential layoffs and the discouraged-worker effect. but instead, the effect of age on labor force participation appears to be constant over time for nonmigrants. This may indicate that the old and the new labor market conditions are similarly disposed to targeting older women (recall by older we mean 40 to 50 year old women) when fewer workers were needed. Alternatively, it may be the case that the reasons for labor force withdrawal of women in our oldest age category (within the prime-age women) has changed over time from voluntary withdrawal to care for grandchildren to involuntary withdrawal due to layoffs or offered early retirement. To tease this out we plan in future work to use much richer but smaller data sets based on surveys that elicit more detailed information about individuals' reasons for not participating in the labor market.

We also plan future work that will compare rural women still living in rural areas with urban women. It will be especially interesting to compare the rural women living in rural areas to the rural migrants enumerated in urban areas. We also plan to look at the labor force participation of older women, that is, those beyond 50 and younger women (16 to 24 years of age) and compare them to the prime-age women featured here. In those comparisons, changes in years of school attendance should figure importantly at the younger ages and changing demographics such as age at first birth and age at marriage along with changing economic conditions and labor market institutions are expected to figure importantly at older ages. 


\section{References}

Cai, Fang, John Giles, and Xin Meng. 2006. "How well do children insure parents against low retirement income? An analysis using survey data from urban China," Journal of Public Economics, 90(12), 2229-2255.

Cai Fang and Meiyan Wang. 2004. "Evolution of urban labor force participation and policy implications" Social Sciences in China. No. 4, accessed online at: http://www.cenet.org.cn/article.asp?articleid=17814

Connelly, Rachel and Zhenzhen Zheng. 2007. "Educational Access for China's PostCultural Revolution Generation: Enrollment Patterns in 1990," Chapter 4, and "Enrollment and Graduation Patterns as China's Reforms Deepen, 19902000," Chapter 5, in Emily Hannum and Albert Park (eds.) Education and Reform in China, Oxford: Routledge.

Connelly, Rachel, Kenneth Roberts, and Zhenzhen Zheng. 2008. "The Role that Children's Education Plays in the Migration Decisions of Chinese Rural Women," unpublished manuscript.

Croll, Elizabeth. 1995. Changing Identities of Chinese Women: Rhetoric, Experience, and Self-Perception in Twentieth-Century China. Atlantic Highlands, NJ: Zed Books.

Entwisle, Barbara and Gail E. Henderson. 2000. ed. Re-drawing Boundaries: Work, Households, and Gender in China. Berkeley: University of California Press.

Frijters, Paul, Leng Lee, and Xin Meng. (forthcoming 2009). "Jobs, Working Hours, and Remuneration Packages of Migrants and Urban Residents," in Tadjuddin Nur Effendi, Shi Li, Chris Manning, Xin Meng (eds.) The Great Migration: Rural-Urban Migration in China and Indonesia, Cheltenham, U.K., Edward Elgar Publishing Limited.

Giles, John and Ren Mu. 2007. "Elderly Parent Health and the Migration Decisions of Adult Children: Evidence from Rural China,” Demography, 44(2), 265-288.

Giles, John, Albert Park, and Fang Cai. 2006. "How Has Economic Restructuring Affected China's Urban Workers?" The China Quarterly, 185(March), 65-91.

Jacka, Tamara. 2006. Rural Women in Urban China: Gender, Migration, and Social Change, Armonk, New York: M. E. Sharpe.

Liu, Lan and Xiaoyuan Dong. 2008. "The Impact of Parental Care on Married Women's Labor Supply: Evidence from Urban China," unpublished manuscript, May. 
Maurer-Fazio, Margaret. 1999. "Education and Earnings in China's Transition to a Market Economy: Survey Evidence from 1989 and 1992," China Economic Review. 10(1), 17-40.

Maurer-Fazio, Margaret. 2006. "In Books One Finds a House of Gold: The Role of Education in Labor Market Outcomes in Urban China." The Journal of Contemporary China 15(47), 215-31.

Maurer-Fazio, Margaret and Ngan Dinh. 2004. "Differential Rewards to, and Contributions of, Education in Urban China's Segmented Labor Markets," Pacific Economic Review, Special Issue October 2004, 9(3), 173-89.

Maurer-Fazio, Margaret, James Hughes, and Dandan Zhang. 2005. "Economic Reform and Changing Patterns of Labor Force Participation in Urban and Rural China," University of Michigan, William Davidson Institute Working Paper Series, August, Working Paper Number 787, 1-39.

Maurer-Fazio, Margaret, James Hughes, and Dandan Zhang. 2007. “An Ocean Formed from One Hundred Rivers: The Effects of Ethnicity, Gender, Marriage, and Location on Labor Force Participation in Urban China," Feminist Economics, July/October, 13(3-4), 125-153.

Maurer-Fazio, Margaret, James Hughes, and Dandan Zhang. 2009. "A Comparison and Decomposition of Reform-Era Labor Force Participation Rates of China's Ethnic Minorities and Han Majority" IZA Discussion Paper Series, May 2009, IZA DP No.4148

Meng, Xin and Chuliang Luo. 2008."What Determines Living Arrangements of the Elderly in Urban China," in Bjorn Gustafsson, Shi Li, and Terry Sicular (eds) Inequality and Public Policy, Cambridge: Cambridge University Press.

Palmer, Michael. 1995. "The Re-Emergence of Family Law in Post-Mao China: Marriage, Divorce and Reproduction,” The China Quarterly, No. 141 Special Issue: China's Legal Reforms, March, 110-134.

Pollert, Anna, 2005, "Gender Transformation and Employment in Central and Eastern Europe," European Journal of Industrial Relations, 11(2), 213-230

Riley, Nancy E. 2004. "China's Population: New Trends and Challenges," Population Bulletin, Vol.59, No.2 (Washington, D.C.: Population Reference Bureau)

Wang, Meiyan and Fang Cai. 2004. "Should I Be Out, or Should I Be In? Labor Force Participation in Transitional Urban China." Institute of Population and Labor Economics, Chinese Academy of Social Science, Working Paper Series No. 38

Yao, Xianguao and Lan Tan, 2005. "Family Income and Labor Force Participation of Married Women in Urban China," Zhejiang University, Labor Economics and Public Policy Working Paper Series, July. 
Zeng, Yi, James W. Vaupel, Zhenyu Xiao, Chunyuan Zhang, and Yuzhi Liu. 2002. "Sociodemographic and Health Profiles of the Oldest Old in China," Population and Development Review, 28(20, 251-273

Zeng, Yi and Zhenglian Wang. 2003, "Dynamics of Family and Elderly Living Arrangements in China: New Lessons Learned from the 2000 Census," The China Review, 3(2), 95-119.

Zhang, Guangyu and Baochang Gu. 2007. "Recent Changes in Marriage Patterns," Transition and Challenge: China's Population at the Beginning of the $21^{\text {st }}$ Century, edited by Zhongwei Zhao and Fei Guo, Oxford: Oxford University Press, 124-139.

Zhang, Hong, (In press) "Active Aging in China: Engaging the Limits of Filial Devotion," a book chapter for the 3rd edition of Cultural Context of Aging: World-Wide Perspective, edited by Jay Sokolovsky.

Zhang, Hong. 2007. "Who Will Care for Our Parents? Changing Boundaries of Family and Public Roles in Providing Care for the Aged in China." Journal of Long Term Home Health Care, 25 (1), 39-46.

Zhang, Hong. 2006. "Family Care or Residential Care? The Moral and Practical Dilemmas Facing the Elderly in Urban China." Asian Anthropology, 5:57-83.

Zhang, Hong. 2005. "Bracing for an Uncertain Future: A Case Study of New Coping Strategies of Rural Parents under China's Birth Control Policy," The China Journal, 53-76.

Zhang, Junsen, Zhao Yaohui, Park, Albert and Song Xiaoqing. 2005. "Economic Returns to Education in Urban China, 1988 to 2001," Journal of Comparative Economics. 33, 730-752. 
Figure 1

Labor Force Participation Rates of Urban, Non-Migrant Women in China by Age $1982,1990, \& 2000$

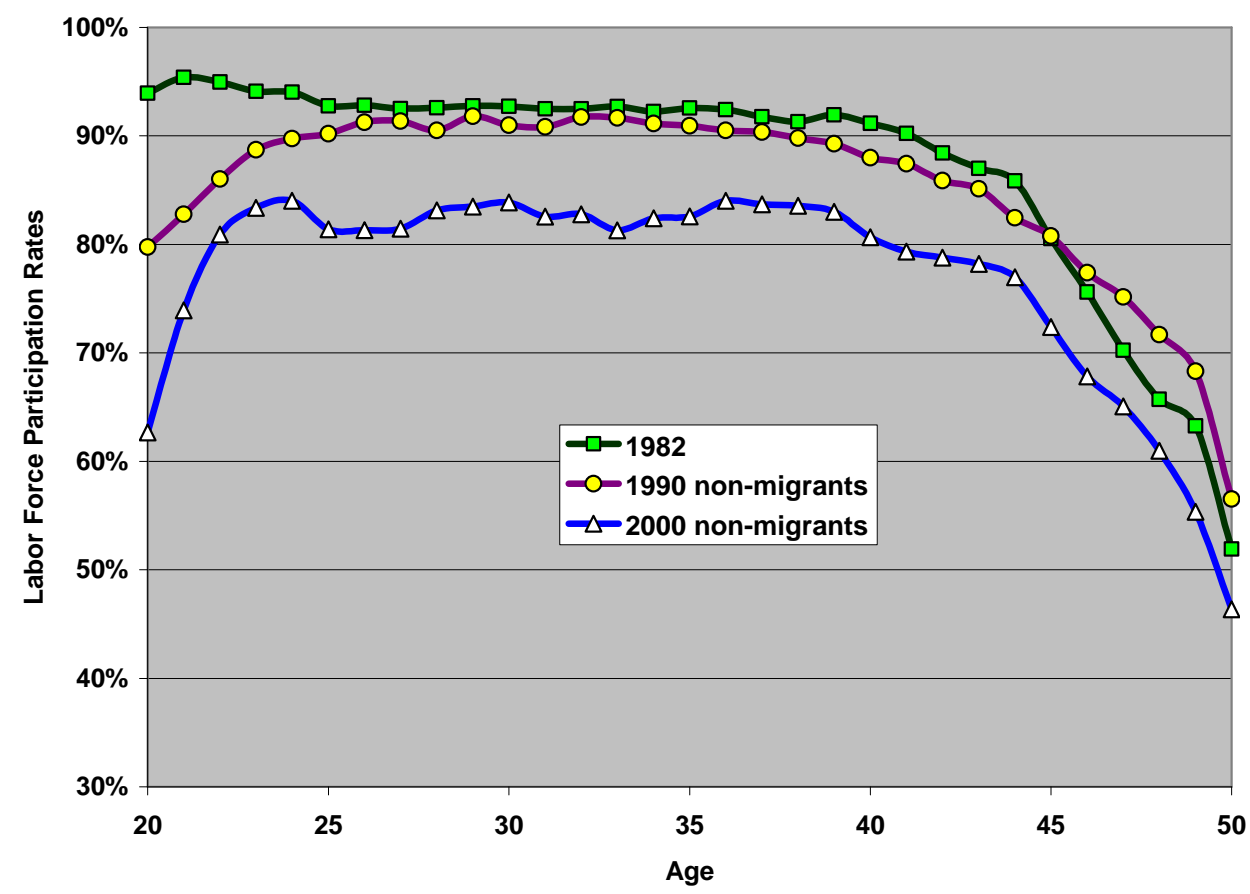

Data Sources: 1\% Micro Samples of the 1982 and 1990 Population Censuses of China and the 0.095\% Micro Sample of the 2000 Population Census of China 
Figure 2

Activity Status of Urban Women Who are Not in the Labor Force, aged 25-50

(as percentage of all rural migrant and non-migrant women aged 25-50)

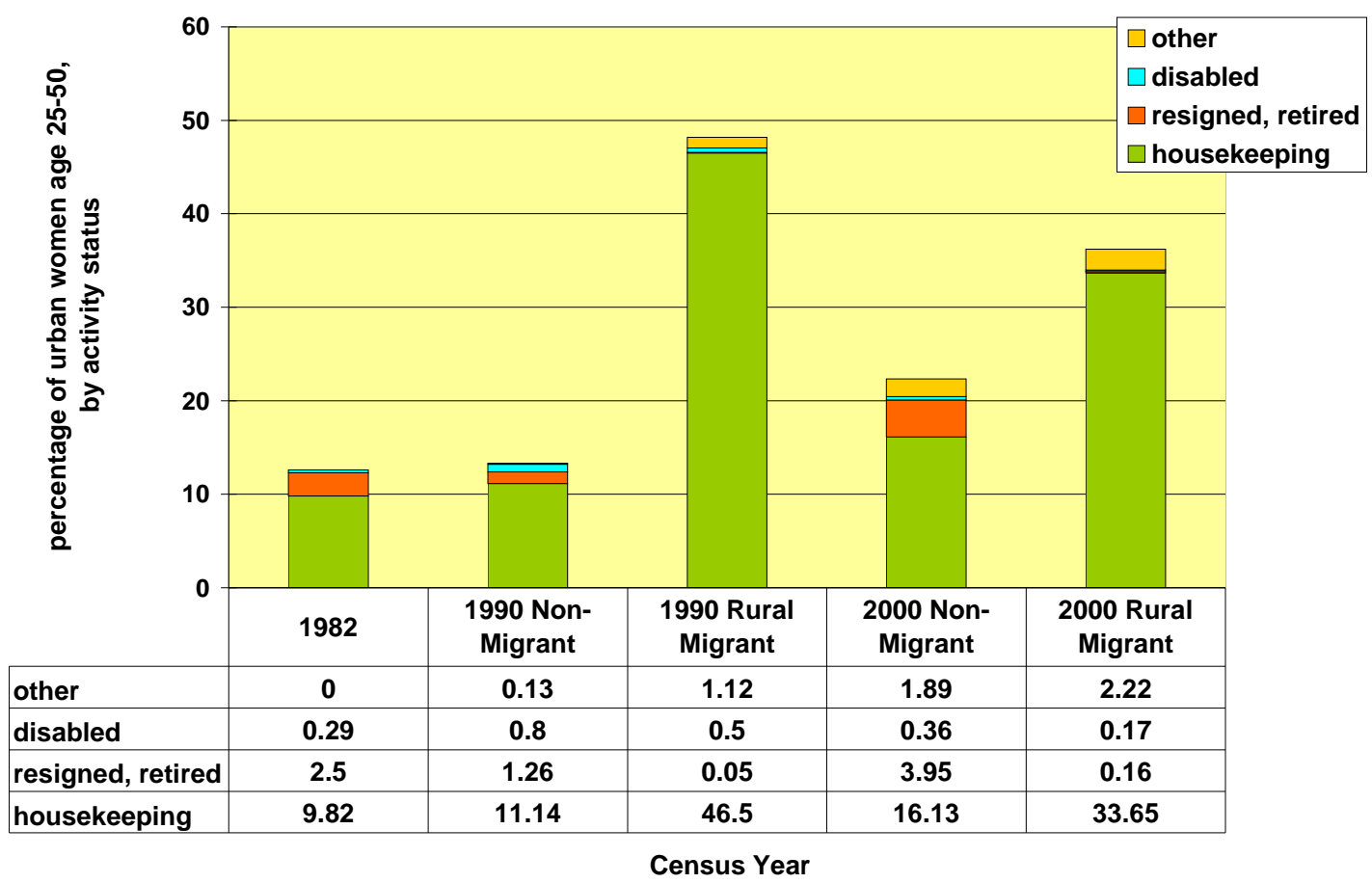

Data Sources: 1\% Micro Samples of the 1982 and 1990 Population Censuses of China and the 0.095\% Micro Sample of the 2000 Population Census of China 
Figure 3

Labor Force Participation Rates of Rural Migrant Women in China by Age $1990 \& 2000$

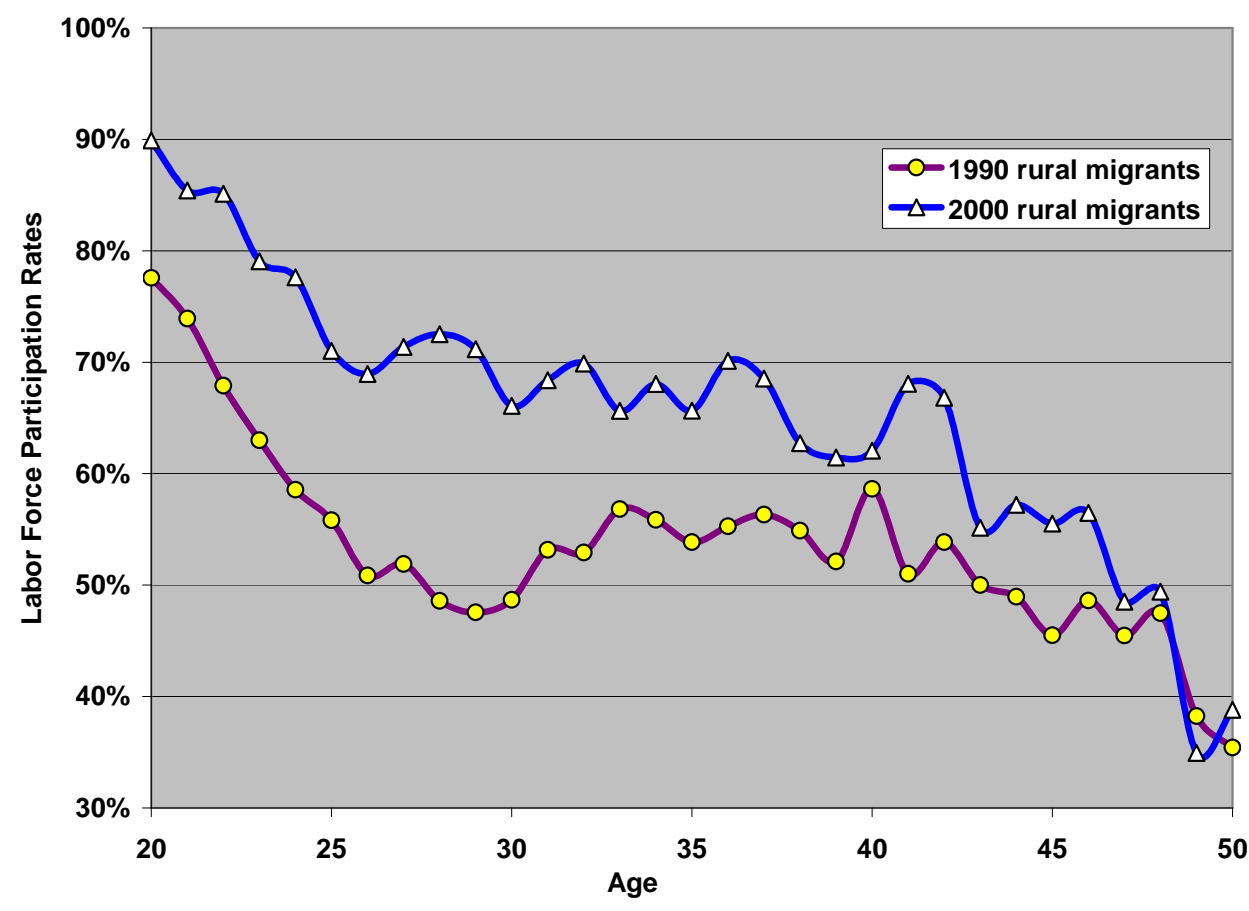

Data Sources: 1\% Micro Samples of the 1990 Population Censuses of China and the $0.095 \%$ Micro Sample of the 2000 Population Census of China 
Figure 4

Mean number of coresident children of married women aged 25-50

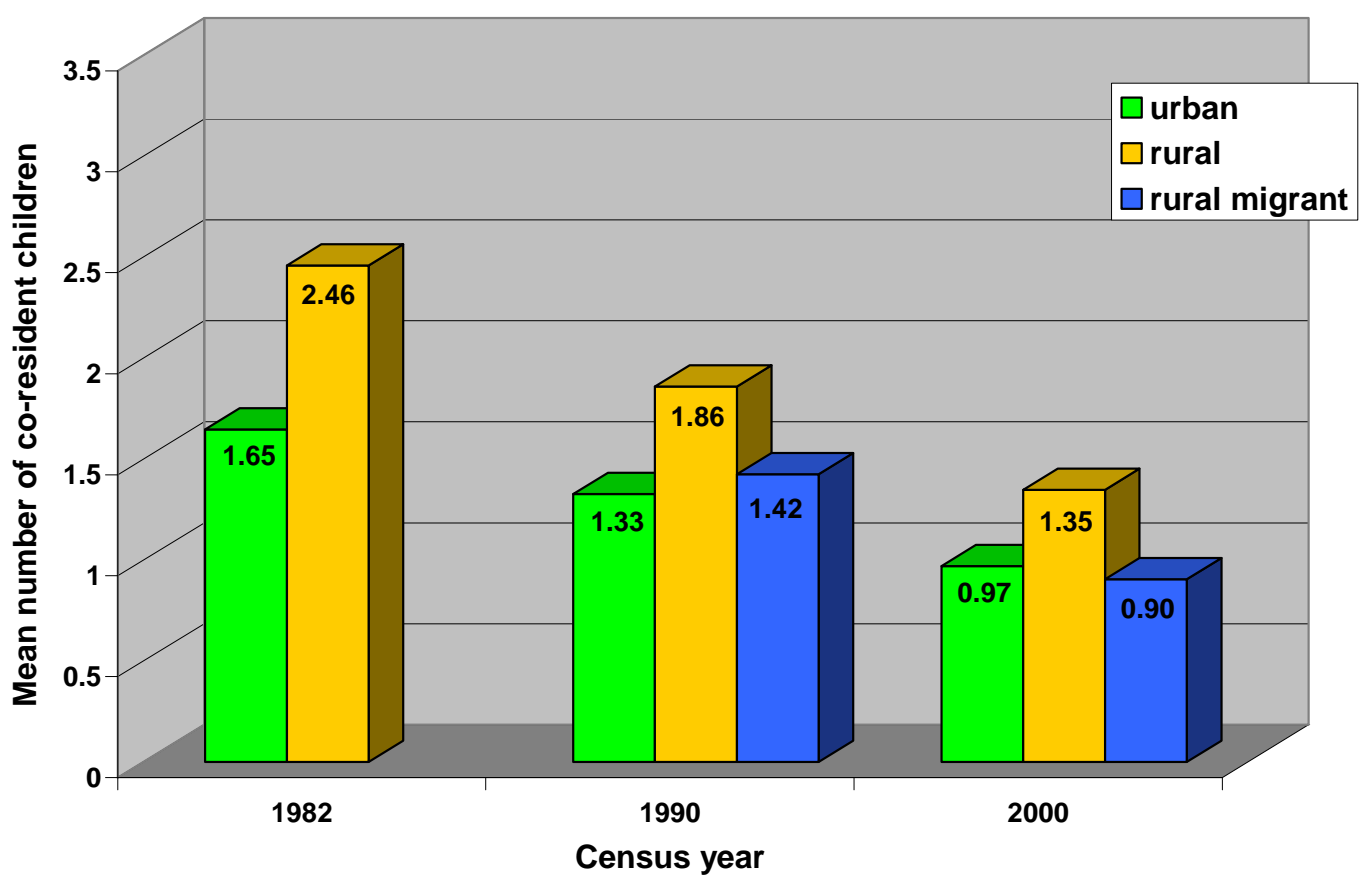

Data Sources: 1\% Micro Samples of the 1982 and 1990 Population Censuses of China and the 0.095\% Micro Sample of the 2000 Population Census of China 
Figure 5

Mean number of surviving children of married women aged 25-50

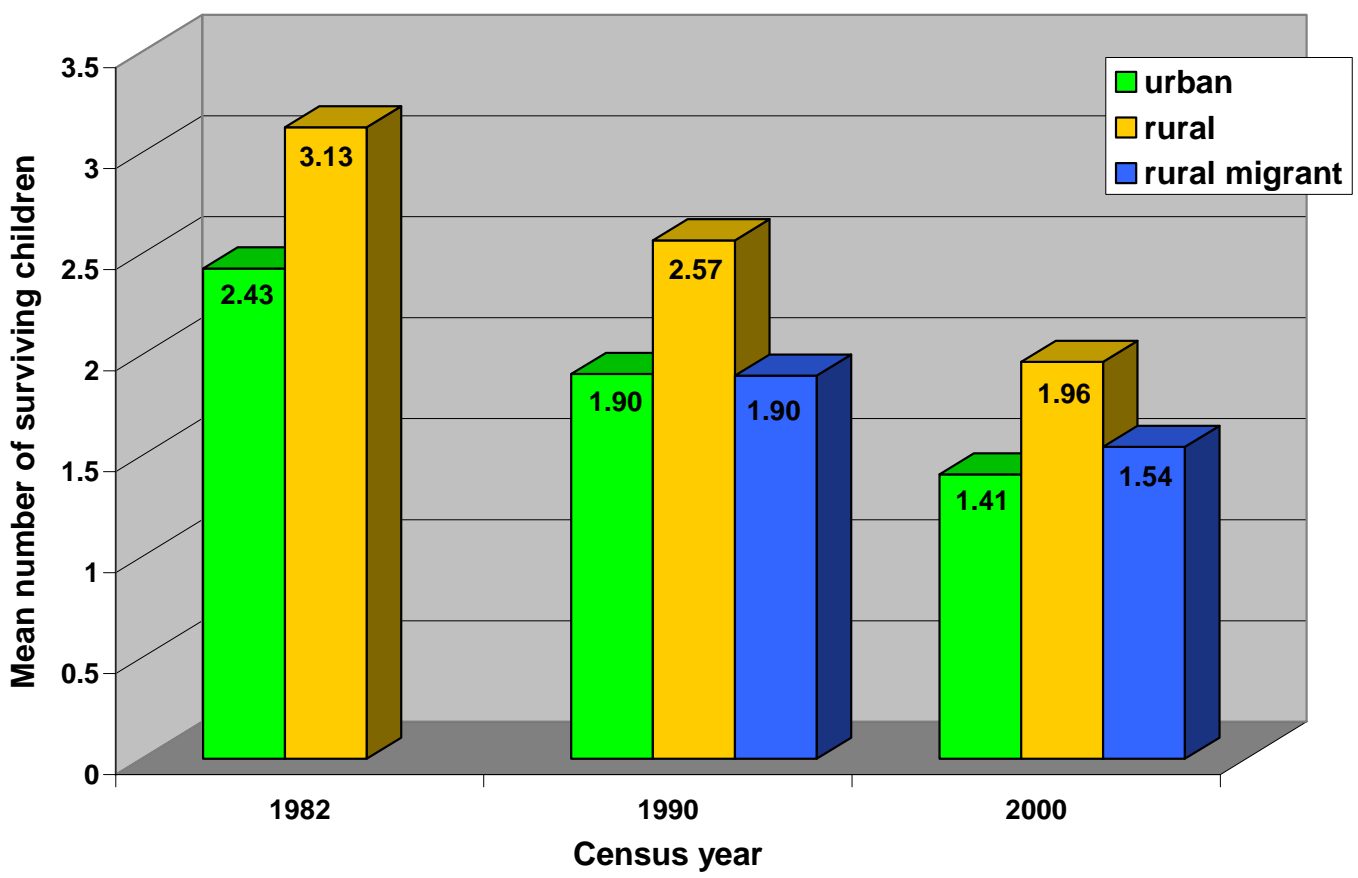

Data Sources: 1\% Micro Samples of the 1982 and 1990 Population Censuses of China and the 0.095\% Micro Sample of the 2000 Population Census of China 
Figure 6

Co-Residency of Migrant Mothers and their Children in 2000

(of mothers in family households)

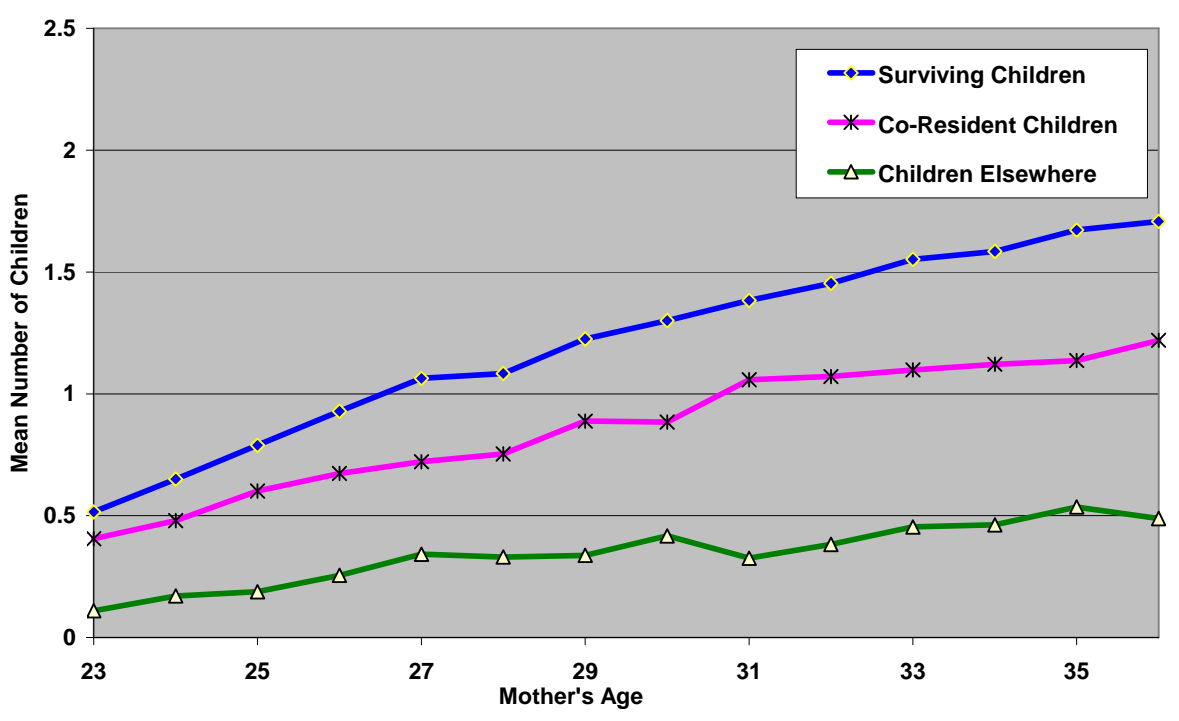

Data Source: $0.095 \%$ Micro Sample of the 2000 Population Census of China 
Figure 7

Co-Residency of Migrant Mothers and their Children in 1990 (of mothers in family households)

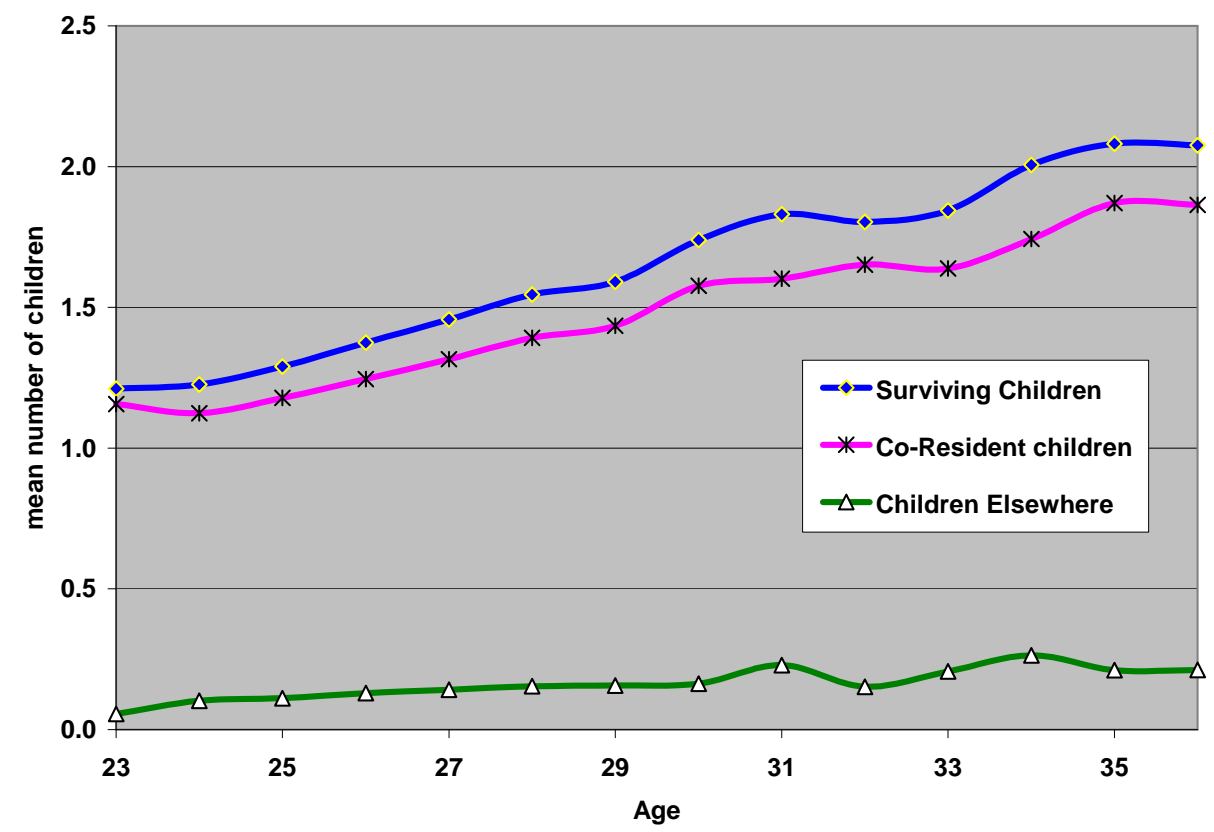

Data Source: 1\% Micro Sample of the 1990 Population Census of China 


\begin{tabular}{|c|c|c|c|c|c|}
\hline \multicolumn{6}{|c|}{$\begin{array}{c}\text { Table 1 } \\
\text { Marginal Effects of the Determinants of Labor Force Participation } \\
\text { Urban, Enumerated, Married, Non-Migrant Women Aged 25-50 in } 2000\end{array}$} \\
\hline Explanatory Variables & $\mathrm{dF} / \mathrm{dx}$ & Std. Err & $z$ & $\mathrm{P}>|\mathrm{z}|$ & x-bar \\
\hline $\begin{array}{l}\text { Co-Residencies } \\
\text { co-resident with parents/parents in-law } \\
\text { co-resident with person aged } 75 \text { or above } \\
\text { co-resident with a disabled person aged less than } 65 \\
\text { number of adults in the household }\end{array}$ & $\begin{array}{l}0.046 \\
0.020 \\
-0.075 \\
0.002\end{array}$ & $\begin{array}{l}0.006 \\
0.009 \\
0.016 \\
0.003\end{array}$ & $\begin{array}{l}7.37 \\
2.19 \\
-4.97 \\
0.81\end{array}$ & $\begin{array}{l}0.000 \\
0.029 \\
0.000 \\
0.420\end{array}$ & $\begin{array}{l}0.192 \\
0.040 \\
0.013 \\
2.575\end{array}$ \\
\hline $\begin{array}{l}\text { Childcare } \\
\text { no children in household, woman age }<=39 \\
\text { youngest co-resident child aged } 0 \text { to } 5 \\
\text { base case: youngest co-resident child aged } 6 \text { to } 12 \\
\text { youngest co-resident child aged } 13 \text { to } 15 \\
\text { youngest co-resident child aged } 16 \text { to } 17 \\
\text { no children in household, woman age }>=40\end{array}$ & $\begin{array}{l}-0.006 \\
-0.042 \\
0.005 \\
-0.002 \\
-0.056\end{array}$ & $\begin{array}{l}0.010 \\
0.006 \\
0.006 \\
0.008 \\
0.007\end{array}$ & $\begin{array}{l}-0.66 \\
-7.29 \\
\\
0.79 \\
-0.24 \\
-7.96\end{array}$ & $\begin{array}{l}0.510 \\
0.000 \\
0.431 \\
0.811 \\
0.000\end{array}$ & $\begin{array}{l}0.042 \\
0.208 \\
0.131 \\
0.065 \\
0.206\end{array}$ \\
\hline $\begin{array}{l}\text { Education Level } \\
\text { illiterate } \\
\text { primary } \\
\text { base case: junior middle } \\
\text { senior middle } \\
\text { post secondary }\end{array}$ & $\begin{array}{l}-0.026 \\
0.008 \\
0.089 \\
0.203 \\
\end{array}$ & $\begin{array}{l}0.010 \\
0.005 \\
0.004 \\
0.003 \\
\end{array}$ & $\begin{array}{r}-2.61 \\
1.76 \\
21.19 \\
30.99 \\
\end{array}$ & $\begin{array}{l}0.009 \\
0.078 \\
0.000 \\
0.000 \\
\end{array}$ & $\begin{array}{l}0.032 \\
0.205 \\
0.251 \\
0.085\end{array}$ \\
\hline $\begin{array}{l}\text { Age Categories } \\
\text { base case: age } 25-29 \\
\text { age } 30-34 \\
\text { age } 35-39 \\
\text { age } 40-44 \\
\text { age } 45-50\end{array}$ & $\begin{array}{r}0.016 \\
0.018 \\
-0.006 \\
-0.127\end{array}$ & $\begin{array}{l}0.006 \\
0.007 \\
0.008 \\
0.010\end{array}$ & $\begin{array}{l}2.61 \\
2.7 \\
-0.72 \\
-13.51 \\
\end{array}$ & $\begin{array}{l}0.009 \\
0.007 \\
0.471 \\
0.000\end{array}$ & $\begin{array}{l}0.221 \\
0.222 \\
0.184 \\
0.207\end{array}$ \\
\hline $\begin{array}{l}\text { Spouse's Education } \\
\text { spouse illiterate } \\
\text { spouse primary } \\
\text { base case: spouse junior middle } \\
\text { spouse senior middle } \\
\text { spouse post secondary }\end{array}$ & $\begin{array}{l}-0.007 \\
0.022 \\
0.000 \\
0.046 \\
\end{array}$ & $\begin{array}{l}0.018 \\
0.005 \\
0.004 \\
0.006 \\
\end{array}$ & $\begin{array}{l}-0.38 \\
4.46 \\
-0.09 \\
7.37 \\
\end{array}$ & $\begin{array}{l}0.703 \\
0.000 \\
0.929 \\
0.000 \\
\end{array}$ & $\begin{array}{l}0.008 \\
0.147 \\
0.265 \\
0.144 \\
\end{array}$ \\
\hline $\begin{array}{l}\text { City/Town Location } \\
\text { resides in a city }\end{array}$ & 0.001 & 0.003 & 0.15 & 0.881 & 0.597 \\
\hline $\begin{array}{l}\text { Muslim Effect } \\
\text { belongs to Muslim ethnic group }(0-1) \\
\% \text { of Muslims in prefectural population }\end{array}$ & $\begin{array}{l}-0.052 \\
-0.046 \\
\end{array}$ & $\begin{array}{l}0.017 \\
0.029\end{array}$ & $\begin{array}{l}-3.27 \\
-1.59 \\
\end{array}$ & $\begin{array}{l}0.001 \\
0.112\end{array}$ & $\begin{array}{l}0.014 \\
0.013\end{array}$ \\
\hline $\begin{array}{l}\text { Other Prefectural Variables } \\
\text { prefectural unemployment rate } \\
\text { prefectural infant sex ratio } \\
\text { prefectural sex difference in illiteracy rate } \\
\end{array}$ & $\begin{array}{r}-0.011 \\
-0.008 \\
0.002\end{array}$ & $\begin{array}{l}0.001 \\
0.004 \\
0.000\end{array}$ & $\begin{array}{l}-19.19 \\
-1.84 \\
4.66 \\
\end{array}$ & $\begin{array}{l}0.000 \\
0.066 \\
0.000\end{array}$ & $\begin{array}{c}4.624 \\
1.233 \\
10.419\end{array}$ \\
\hline $\begin{array}{l}\text { Provincial Income Variables } \\
\text { provincial urban real per capita income (100 yuan) } \\
\text { provincial urban real per capita income squared } \\
\text { provincial annual real GDP growth rate over previous } 5 \text { years }\end{array}$ & $\begin{array}{l}0.004 \\
0.000 \\
0.007\end{array}$ & $\begin{array}{l}0.001 \\
0.000 \\
0.002\end{array}$ & $\begin{array}{l}5.09 \\
-4.53 \\
4.35\end{array}$ & $\begin{array}{l}0.000 \\
0.000 \\
0.000\end{array}$ & $\begin{array}{c}64.395 \\
4454.650 \\
9.090\end{array}$ \\
\hline $\begin{array}{l}\text { observed P } \\
\text { predicted } \mathrm{P}\end{array}$ & $\begin{array}{l}0.773 \\
0.796\end{array}$ & (at x-bar) & & & \\
\hline $\begin{array}{l}\text { Number of obs } \\
\text { LR chi2(22) } \\
\text { Prob > chi2 } \\
\text { Pseudo R2 } \\
\text { Log likelihood }\end{array}$ & $\begin{array}{c}62,846 \\
5,382 \\
0.000 \\
0.080 \\
-30,972 \\
\end{array}$ & & & & \\
\hline
\end{tabular}

Data Source: $0.095 \%$ Micro Sample of the 2000 Population Census of China 


\begin{tabular}{|c|c|c|c|c|c|}
\hline $\begin{array}{l}\text { Marginal Effects of the Determina } \\
\text { Urban, Enumerated, Married, Non- } \\
\text { (Using predicted values of co-residency wi }\end{array}$ & $\begin{array}{l}\text { of Lal } \\
\text { ant W } \\
\text { arent }\end{array}$ & $\begin{array}{l}\text { Force P } \\
\text { ien Aged } \\
\text {-laws, e }\end{array}$ & $\begin{array}{l}\text { tici } \\
5-50 \\
\text { ers, }\end{array}$ & g chil & \\
\hline Explanatory Variables & $\mathrm{dF} / \mathrm{dx}$ & Std. Err & $z$ & $P>|z|$ & $x$-bar \\
\hline $\begin{array}{l}\text { Co-Residencies } \\
\text { predicted: co-resident with parents/parents in-law } \\
\text { predicted: co-resident with person aged } 75 \text { or above } \\
\text { co-resident with a disabled person aged less than } 65 \\
\text { number of adults in the household } \\
\end{array}$ & $\begin{array}{r}0.115 \\
0.126 \\
-0.079 \\
-0.028 \\
\end{array}$ & $\begin{array}{l}0.014 \\
0.037 \\
0.017 \\
0.006\end{array}$ & $\begin{array}{l}8.12 \\
3.36 \\
-5.16 \\
-4.86 \\
\end{array}$ & $\begin{array}{l}0.000 \\
0.001 \\
0.000 \\
0.000 \\
\end{array}$ & $\begin{array}{l}0.186 \\
0.040 \\
0.013 \\
2.576\end{array}$ \\
\hline $\begin{array}{l}\text { Childcare } \\
\text { no children in household, woman age }<=39 \\
\text { predicted: youngest co-resident child aged } 0 \text { to } 5 \\
\text { base case: youngest co-resident child aged } 6 \text { to } 12 \\
\text { youngest co-resident child aged } 13 \text { to } 15 \\
\text { youngest co-resident child aged } 16 \text { to } 17 \\
\text { no children in household, woman age }>=40 \\
\end{array}$ & $\begin{array}{r}0.015 \\
-0.058 \\
\\
0.009 \\
0.001 \\
-0.050 \\
\end{array}$ & $\begin{array}{l}0.009 \\
0.019 \\
0.006 \\
0.008 \\
0.007 \\
\end{array}$ & $\begin{array}{l}1.62 \\
-2.97 \\
\\
1.52 \\
0.15 \\
-7.18 \\
\end{array}$ & $\begin{array}{l}0.106 \\
0.003 \\
0.127 \\
0.878 \\
0.000 \\
\end{array}$ & $\begin{array}{l}0.042 \\
0.208 \\
0.131 \\
0.065 \\
0.206 \\
\end{array}$ \\
\hline $\begin{array}{l}\text { Education Level } \\
\text { illiterate } \\
\text { primary } \\
\text { base case: junior middle } \\
\text { senior middle } \\
\text { post secondary }\end{array}$ & $\begin{array}{l}-0.016 \\
0.010 \\
0.088 \\
0.203 \\
\end{array}$ & $\begin{array}{l}0.010 \\
0.005 \\
0.004 \\
0.003 \\
\end{array}$ & $\begin{array}{l}-1.67 \\
2.07 \\
20.89 \\
30.82 \\
\end{array}$ & $\begin{array}{l}0.095 \\
0.039 \\
0.000 \\
0.000 \\
\end{array}$ & $\begin{array}{l}0.032 \\
0.205 \\
0.251 \\
0.085 \\
\end{array}$ \\
\hline $\begin{array}{l}\text { Age Categories } \\
\text { base case: age } 25-29 \\
\text { age } 30-34 \\
\text { age } 35-39 \\
\text { age } 40-44 \\
\text { age } 45-50\end{array}$ & $\begin{array}{r}0.012 \\
0.008 \\
-0.010 \\
-0.122\end{array}$ & $\begin{array}{l}0.009 \\
0.013 \\
0.015 \\
0.018\end{array}$ & $\begin{array}{l}1.31 \\
0.59 \\
-0.71 \\
-7.42\end{array}$ & $\begin{array}{l}0.191 \\
0.552 \\
0.479 \\
0.000\end{array}$ & $\begin{array}{l}0.221 \\
0.222 \\
0.184 \\
0.207\end{array}$ \\
\hline $\begin{array}{l}\text { Spouse's Education } \\
\text { spouse illiterate } \\
\text { spouse primary } \\
\text { base case: spouse junior middle } \\
\text { spouse senior middle } \\
\text { spouse post secondary }\end{array}$ & $\begin{array}{r}-0.006 \\
0.023 \\
-0.001 \\
0.047 \\
\end{array}$ & $\begin{array}{l}0.018 \\
0.005 \\
0.004 \\
0.006 \\
\end{array}$ & $\begin{array}{r}-0.32 \\
4.55 \\
-0.15 \\
7.59 \\
\end{array}$ & $\begin{array}{l}0.753 \\
0.000 \\
0.879 \\
0.000 \\
\end{array}$ & $\begin{array}{l}0.008 \\
0.147 \\
0.265 \\
0.144 \\
\end{array}$ \\
\hline $\begin{array}{l}\text { City/Town Location } \\
\text { resides in a city }\end{array}$ & 0.000 & 0.003 & 0.14 & 0.891 & 0.597 \\
\hline $\begin{array}{l}\text { Muslim Effect } \\
\text { belongs to Muslim ethnic group }(0-1) \\
\% \text { of Muslims in prefectural population }\end{array}$ & $\begin{array}{l}-0.052 \\
-0.032 \\
\end{array}$ & $\begin{array}{l}0.017 \\
0.030 \\
\end{array}$ & $\begin{array}{l}-3.21 \\
-1.06 \\
\end{array}$ & $\begin{array}{l}0.001 \\
0.289 \\
\end{array}$ & $\begin{array}{l}0.013 \\
0.012 \\
\end{array}$ \\
\hline $\begin{array}{l}\text { Other Prefectural Variables } \\
\text { prefectural unemployment rate } \\
\text { prefectural infant sex ratio } \\
\text { prefectural sex difference in illiteracy rate } \\
\end{array}$ & $\begin{array}{l}-0.011 \\
-0.008 \\
0.002 \\
\end{array}$ & $\begin{array}{l}0.001 \\
0.004 \\
0.000 \\
\end{array}$ & $\begin{array}{l}-19.12 \\
-1.9 \\
5.05 \\
\end{array}$ & $\begin{array}{l}0.000 \\
0.058 \\
0.000\end{array}$ & $\begin{array}{c}4.631 \\
1.233 \\
10.402 \\
\end{array}$ \\
\hline $\begin{array}{l}\text { Provincial Income Variables } \\
\text { provincial urban real per capita income (100 yuan) } \\
\text { provincial urban real per capita income squared } \\
\text { provincial annual real GDP growth rate over previous } 5 \text { years }\end{array}$ & $\begin{array}{l}0.004 \\
0.000 \\
0.006\end{array}$ & $\begin{array}{l}0.001 \\
0.000 \\
0.002\end{array}$ & $\begin{array}{l}4.88 \\
-4.38 \\
3.99\end{array}$ & $\begin{array}{l}0.000 \\
0.000 \\
0.000\end{array}$ & $\begin{array}{c}64.404 \\
4456.320 \\
9.092\end{array}$ \\
\hline $\begin{array}{l}\text { observed P } \\
\text { predicted P }\end{array}$ & $\begin{array}{l}0.773 \\
0.796\end{array}$ & (at x-bar) & & & \\
\hline $\begin{array}{l}\text { Number of obs } \\
\text { LR chi2(22) } \\
\text { Prob > chi2 } \\
\text { Pseudo R2 } \\
\text { Log likelihood }\end{array}$ & $\begin{array}{c}62,712 \\
5,330 \\
0.000 \\
0.079 \\
-30,916\end{array}$ & & & & \\
\hline
\end{tabular}

Data Source: $0.095 \%$ Micro Sample of the 2000 Population Census of China 


\begin{tabular}{|c|c|c|c|c|c|c|c|c|c|}
\hline $\begin{array}{l}\text { Marginal Effects of the Dete } \\
\text { Urban, Enumerated, Married, Non-Mi }\end{array}$ & $\begin{array}{l}\text { ble } \\
\text { nan } \\
\text { nt V }\end{array}$ & $e$ & $\begin{array}{l}\text { abo } \\
\mathrm{Ag}\end{array}$ & $\begin{array}{l}\text { orc } \\
25\end{array}$ & in & $\begin{array}{l}\text { cipa } \\
982,\end{array}$ & $\begin{array}{l}\text { on } \\
990 \&\end{array}$ & 200 & \\
\hline & & 1982 & & & 1990 & & & 2000 & \\
\hline Explanatory Variables & $\mathrm{dF} / \mathrm{dx}$ & Sig. & $x$-bar & $\mathrm{dF} / \mathrm{dx}$ & Sig. & $x$-bar & $\mathrm{dF} / \mathrm{dx}$ & Sig. & $x$-bar \\
\hline $\begin{array}{l}\text { Co-Residencies } \\
\text { co-resident with parents/parents in-law } \\
\text { co-resident with person aged } 75 \text { or above } \\
\text { co-resident with a disabled person aged less than } 65 \\
\text { number of adults in the household } \\
\end{array}$ & $\begin{array}{r}0.027 \\
0.000 \\
-0.119 \\
-0.012 \\
\end{array}$ & $\begin{array}{c}* \star * \\
\star * * \\
\star \star \star \\
\end{array}$ & $\begin{array}{l}0.194 \\
0.038 \\
0.012 \\
2.837 \\
\end{array}$ & $\begin{array}{r}0.026 \\
0.003 \\
-0.059 \\
-0.007 \\
\end{array}$ & $\begin{array}{l}* \star * \\
* \star \star \\
* \star \star\end{array}$ & $\begin{array}{l}0.180 \\
0.040 \\
0.008 \\
2.659 \\
\end{array}$ & $\begin{array}{r}0.046 \\
0.020 \\
-0.075 \\
0.002 \\
\end{array}$ & $\begin{array}{c}* \star * \\
* * \\
* * *\end{array}$ & $\begin{array}{l}0.192 \\
0.040 \\
0.013 \\
2.575 \\
\end{array}$ \\
\hline $\begin{array}{l}\text { Childcare } \\
\text { no children in household, woman age }<=39 \\
\text { youngest co-resident child aged } 0 \text { to } 5 \\
\text { base case: youngest co-resident child aged } 6 \text { to } 12 \\
\text { youngest co-resident child aged } 13 \text { to } 15 \\
\text { youngest co-resident child aged } 16 \text { to } 17 \\
\text { no children in household, woman age }>=40\end{array}$ & $\begin{array}{r}0.018 \\
-0.026 \\
\\
0.015 \\
-0.001 \\
-0.025 \\
\end{array}$ & $\begin{array}{l}* * * \\
* * * \\
* * \star \\
* * \star\end{array}$ & $\begin{array}{l}0.056 \\
0.373 \\
0.088 \\
0.044 \\
0.089 \\
\end{array}$ & $\begin{array}{r}0.002 \\
-0.035 \\
-0.005 \\
-0.006 \\
-0.030 \\
\end{array}$ & \begin{tabular}{c|}
$* * *$ \\
$* *$ \\
$*$ \\
$* * *$ \\
\end{tabular} & $\begin{array}{l}0.040 \\
0.346 \\
0.107 \\
0.058 \\
0.093 \\
\end{array}$ & $\begin{array}{l}-0.006 \\
-0.042 \\
\\
0.005 \\
-0.002 \\
-0.056 \\
\end{array}$ & $* * *$ & $\begin{array}{l}0.042 \\
0.208 \\
0.131 \\
0.065 \\
0.206 \\
\end{array}$ \\
\hline $\begin{array}{l}\text { Education Level } \\
\text { illiterate } \\
\text { primary } \\
\text { base case: junior middle } \\
\text { senior middle } \\
\text { post secondary }\end{array}$ & $\begin{array}{l}-0.156 \\
-0.092 \\
0.037 \\
0.059 \\
\end{array}$ & $\begin{array}{l}* * * \\
* * * \\
* * * \\
* * *\end{array}$ & $\begin{array}{l}0.216 \\
0.325 \\
0.123 \\
0.028 \\
\end{array}$ & $\begin{array}{l}-0.094 \\
-0.057 \\
0.063 \\
0.092 \\
\end{array}$ & \begin{tabular}{l|}
$* * *$ \\
$* * *$ \\
$* * *$ \\
$* * *$
\end{tabular} & $\begin{array}{l}0.117 \\
0.282 \\
0.228 \\
0.036 \\
\end{array}$ & $\begin{array}{l}-0.026 \\
0.008 \\
0.089 \\
0.203 \\
\end{array}$ & $\begin{array}{c}* * * \\
* \\
* * * \\
* * *\end{array}$ & $\begin{array}{l}0.032 \\
0.205 \\
0.251 \\
0.085 \\
\end{array}$ \\
\hline $\begin{array}{l}\text { Age Categories } \\
\text { base case: age } 25-29 \\
\text { age } 30-34 \\
\text { age } 35-39 \\
\text { age } 40-44 \\
\text { age } 45-50 \\
\end{array}$ & $\begin{array}{r}0.017 \\
0.009 \\
0.000 \\
-0.123 \\
\end{array}$ & $\begin{array}{l}* * * \\
* * * \\
* * * \\
\end{array}$ & $\begin{array}{l}0.217 \\
0.168 \\
0.175 \\
0.195 \\
\end{array}$ & $\begin{array}{r}0.008 \\
0.012 \\
-0.011 \\
-0.110 \\
\end{array}$ & $\begin{array}{l}* * * \\
* * * \\
* * * \\
* * * \\
\end{array}$ & $\begin{array}{l}0.230 \\
0.229 \\
0.159 \\
0.142 \\
\end{array}$ & $\begin{array}{r}0.016 \\
0.018 \\
-0.006 \\
-0.127 \\
\end{array}$ & $\begin{array}{l}* * * \\
* * * \\
* * *\end{array}$ & $\begin{array}{l}0.221 \\
0.222 \\
0.184 \\
0.207 \\
\end{array}$ \\
\hline $\begin{array}{l}\text { Spouse's Education } \\
\text { spouse illiterate } \\
\text { spouse primary } \\
\text { base case: spouse junior middle } \\
\text { spouse senior middle } \\
\text { spouse post secondary }\end{array}$ & $\begin{array}{l}-0.038 \\
-0.027 \\
0.010 \\
0.033 \\
\end{array}$ & \begin{tabular}{|l|}
$* * *$ \\
$* * *$ \\
\\
$* * *$ \\
$* * *$
\end{tabular} & $\begin{array}{l}0.082 \\
0.336 \\
\\
0.146 \\
0.070 \\
\end{array}$ & $\begin{array}{l}-0.043 \\
-0.020 \\
\\
0.018 \\
0.045 \\
\end{array}$ & \begin{tabular}{l|}
$* * *$ \\
$* \star \star$ \\
$* * \star$ \\
$* \star *$
\end{tabular} & $\begin{array}{l}0.038 \\
0.241 \\
\\
0.245 \\
0.088 \\
\end{array}$ & $\begin{array}{l}-0.007 \\
0.022 \\
\\
0.000 \\
0.046 \\
\end{array}$ & $* * *$ & $\begin{array}{l}0.008 \\
0.147 \\
\\
0.265 \\
0.144 \\
\end{array}$ \\
\hline $\begin{array}{l}\text { City/Town Location } \\
\text { resides in a city }\end{array}$ & & & & 0.038 & *** & 0.414 & 0.001 & & 0.597 \\
\hline $\begin{array}{l}\text { Muslim Effect } \\
\text { belongs to Muslim ethnic group }(0-1) \\
\% \text { of Muslims in prefectural population }\end{array}$ & $\begin{array}{l}-0.020 \\
-0.001 \\
\end{array}$ & ${ }_{* * *}^{*}$ & $\begin{array}{l}0.017 \\
1.600 \\
\end{array}$ & $\begin{array}{l}-0.038 \\
0.000 \\
\end{array}$ & $\begin{array}{c}* * * \\
* \\
\end{array}$ & $\begin{array}{l}0.014 \\
1.380 \\
\end{array}$ & $\begin{array}{l}-0.052 \\
-0.046 \\
\end{array}$ & $* \star *$ & $\begin{array}{l}0.014 \\
0.013 \\
\end{array}$ \\
\hline $\begin{array}{l}\text { Other Prefectural Variables } \\
\text { prefectural unemployment rate } \\
\text { prefectural infant sex ratio } \\
\text { prefectural sex difference in illiteracy rate }\end{array}$ & $\begin{array}{r}-0.020 \\
0.038 \\
0.002 \\
\end{array}$ & $\begin{array}{c}* * \star \\
\star * \star \\
* * \star \\
\end{array}$ & $\begin{array}{c}1.590 \\
1.083 \\
20.402 \\
\end{array}$ & $\begin{array}{r}-0.019 \\
0.115 \\
0.002 \\
\end{array}$ & $\begin{array}{c}* \star \star \\
* \star \star \\
* \star \star\end{array}$ & $\begin{array}{r}1.246 \\
1.119 \\
16.157 \\
\end{array}$ & $\begin{array}{l}-0.011 \\
-0.008 \\
0.002 \\
\end{array}$ & $\begin{array}{c}* * * \\
* \\
* \star * \\
\end{array}$ & $\begin{array}{c}4.624 \\
1.233 \\
10.419 \\
\end{array}$ \\
\hline $\begin{array}{l}\text { Provincial Income Variables } \\
\text { provincial urban real per capita income ( } 100 \text { yuan) } \\
\text { provincial urban real per capita income squared } \\
\text { provincial annual real GDP growth rate over previous } 5 \text { years }\end{array}$ & $\begin{array}{l}-0.002 \\
0.000 \\
0.008\end{array}$ & $* * *$ & $\begin{array}{c}18.932 \\
382.2 \\
9.144\end{array}$ & $\begin{array}{r}0.012 \\
0.000 \\
-0.007\end{array}$ & $\begin{array}{l}* * * \\
\star * * \\
\star * * \\
\end{array}$ & $\begin{array}{c}29.193 \\
902.7 \\
5.948\end{array}$ & $\begin{array}{l}0.004 \\
0.000 \\
0.007\end{array}$ & $\begin{array}{c}* * * \\
* * * \\
* * *\end{array}$ & $\begin{array}{c}64.395 \\
4454.7 \\
9.090\end{array}$ \\
\hline $\begin{array}{l}\text { observed P } \\
\text { predicted P }\end{array}$ & $\begin{array}{l}0.867 \\
0.908\end{array}$ & & & $\begin{array}{l}0.870 \\
0.906\end{array}$ & & & $\begin{array}{l}0.773 \\
0.796\end{array}$ & & \\
\hline $\begin{array}{l}\text { Number of obs } \\
\text { LR chi2(22) } \\
\text { Prob > chi2 } \\
\text { Pseudo R2 } \\
\text { Log likelihood }\end{array}$ & $\begin{array}{c}188,045 \\
25,752 \\
0.000 \\
0.175 \\
-60,686 \\
\end{array}$ & & & $\begin{array}{c}213,915 \\
24,005 \\
0.000 \\
0.145 \\
-70,707 \\
\end{array}$ & & & $\begin{array}{c}62,846 \\
5,382 \\
0.000 \\
0.080 \\
-30,972 \\
\end{array}$ & & \\
\hline
\end{tabular}

Data Sources: 1\% Micro Samples of the 1982 and 1990 Population Censuses of China and the 0.095\% Micro Sample of the 2000 Population Census of China

Significance Levels: ${ }^{* * *}$ significant at $1 \%$; ${ }^{* *}$ significant at $5 \%$; * significant at $10 \%$ 


\begin{tabular}{|c|c|c|c|c|c|c|c|c|c|}
\hline $\begin{array}{l}\text { Marginal Effects of the Det } \\
\text { Urban, Enumerated, Married, Non-M } \\
\text { (Using predicted values of co-reside }\end{array}$ & $\begin{array}{l}\text { able } \\
\text { inan } \\
\text { ant } \mathrm{n} \\
\text { with }\end{array}$ & e & $\begin{array}{l}\text { Labo } \\
\text { n Ag } \\
\text { nts/i }\end{array}$ & $\begin{array}{l}\text { orce } \\
25-50 \\
\text { aws, }\end{array}$ & $\begin{array}{l}\text { Part } \\
\text { in } \\
\text { adde }\end{array}$ & $\begin{array}{l}\text { ticipa } \\
1982, \\
\text { rs, yo }\end{array}$ & $\begin{array}{l}\text { on } \\
990 \text { \& } \\
\text { ng cl }\end{array}$ & $\begin{array}{l}00 \\
\text { Ire }\end{array}$ & \\
\hline & & 1982 & & & 1990 & & & 2000 & \\
\hline Explanatory Variables & $\mathrm{dF} / \mathrm{dx}$ & Sig. & $x$-bar & $\mathrm{dF} / \mathrm{dx}$ & Sig. & $x$-bar & $\mathrm{dF} / \mathrm{dx}$ & Sig. & $x$-bar \\
\hline $\begin{array}{l}\text { Co-Residencies } \\
\text { predicted: co-resident with parents/parents in-law } \\
\text { predicted: co-resident with person aged } 75 \text { or above } \\
\text { co-resident with a disabled person aged less than } 65 \\
\text { number of adults in the household } \\
\end{array}$ & $\begin{array}{c}0.079 \\
-0.024 \\
-0.129 \\
-0.022 \\
\end{array}$ & \begin{tabular}{|l|}
$* * *$ \\
\\
$* * *$ \\
$* * *$ \\
\end{tabular} & $\begin{array}{l}0.189 \\
0.038 \\
0.012 \\
2.838 \\
\end{array}$ & $\begin{array}{r}0.086 \\
0.028 \\
-0.071 \\
-0.025 \\
\end{array}$ & $\begin{array}{c}* * * \\
* \\
* * * \\
* * *\end{array}$ & $\begin{array}{l}0.174 \\
0.039 \\
0.008 \\
2.659 \\
\end{array}$ & $\begin{array}{r}0.115 \\
0.126 \\
-0.079 \\
-0.028 \\
\end{array}$ & \begin{tabular}{|c|}
$* * *$ \\
$* * \star$ \\
$* \star \star$ \\
$* * \star$ \\
\end{tabular} & $\begin{array}{l}0.186 \\
0.040 \\
0.013 \\
2.576 \\
\end{array}$ \\
\hline $\begin{array}{l}\text { Childcare } \\
\text { no children in household, woman age }<=39 \\
\text { predicted: youngest co-resident child aged } 0 \text { to } 5 \\
\text { base case: youngest co-resident child aged } 6 \text { to } 12 \\
\text { youngest co-resident child aged } 13 \text { to } 15 \\
\text { youngest co-resident child aged } 16 \text { to } 17 \\
\text { no children in household, woman age }>=40 \\
\end{array}$ & $\begin{array}{r}0.035 \\
0.049 \\
\\
0.018 \\
0.002 \\
-0.023 \\
\end{array}$ & $\begin{array}{l}* * * \\
* * * \\
* * * \\
* \star *\end{array}$ & $\begin{array}{l}0.056 \\
0.373 \\
\\
0.088 \\
0.044 \\
0.089 \\
\end{array}$ & $\begin{array}{r}0.021 \\
-0.030 \\
\\
0.002 \\
0.002 \\
-0.021 \\
\end{array}$ & $\begin{array}{c}* * \star \\
* * \star\end{array}$ & $\begin{array}{l}0.040 \\
0.346 \\
\\
0.107 \\
0.058 \\
0.093 \\
\end{array}$ & $\begin{array}{l}0.015 \\
-0.058 \\
\\
0.009 \\
0.001 \\
-0.050 \\
\end{array}$ & *** & $\begin{array}{l}0.042 \\
0.208 \\
0.131 \\
0.065 \\
0.206 \\
\end{array}$ \\
\hline $\begin{array}{l}\text { Education Level } \\
\text { illiterate } \\
\text { primary } \\
\text { base case: junior middle } \\
\text { senior middle } \\
\text { post secondary } \\
\end{array}$ & $\begin{array}{l}-0.156 \\
-0.090 \\
0.036 \\
0.057 \\
\end{array}$ & $\begin{array}{l}* \star * \\
\star * \star \\
\star * \star \\
\star * * \\
\end{array}$ & $\begin{array}{l}0.216 \\
0.325 \\
0.123 \\
0.028 \\
\end{array}$ & $\begin{array}{l}-0.091 \\
-0.055 \\
0.063 \\
0.092\end{array}$ & $\begin{array}{c}* * \star \\
* * \star \\
\star * * \\
* * \star\end{array}$ & $\begin{array}{l}0.117 \\
0.282 \\
0.228 \\
0.036 \\
\end{array}$ & $\begin{array}{l}-0.016 \\
0.010 \\
0.088 \\
0.203\end{array}$ & $\begin{array}{c}* \\
* * \\
* * * \\
* \star \star \\
\end{array}$ & $\begin{array}{l}0.032 \\
0.205 \\
0.251 \\
0.085 \\
\end{array}$ \\
\hline $\begin{array}{l}\text { Age Categories } \\
\text { base case: age } 25-29 \\
\text { age } 30-34 \\
\text { age } 35-39 \\
\text { age } 40-44 \\
\text { age } 45-50\end{array}$ & $\begin{array}{r}0.033 \\
0.052 \\
0.056 \\
-0.027 \\
\end{array}$ & \begin{tabular}{l|}
$* * *$ \\
$\star * *$ \\
$* * *$ \\
$* * *$ \\
\end{tabular} & $\begin{array}{l}0.217 \\
0.168 \\
0.175 \\
0.195 \\
\end{array}$ & $\begin{array}{l}0.010 \\
0.015 \\
-0.001 \\
-0.085 \\
\end{array}$ & $\begin{array}{c}* * * \\
* * * \\
* * *\end{array}$ & $\begin{array}{l}0.230 \\
0.229 \\
0.159 \\
0.142 \\
\end{array}$ & $\begin{array}{c}0.012 \\
0.008 \\
-0.010 \\
-0.122 \\
\end{array}$ & $* \star \star$ & $\begin{array}{l}0.221 \\
0.222 \\
0.184 \\
0.207 \\
\end{array}$ \\
\hline $\begin{array}{l}\text { Spouse's Education } \\
\text { spouse illiterate } \\
\text { spouse primary } \\
\text { base case: spouse junior middle } \\
\text { spouse senior middle } \\
\text { spouse post secondary }\end{array}$ & $\begin{array}{l}-0.037 \\
-0.026 \\
0.011 \\
0.032 \\
\end{array}$ & $\begin{array}{l}* * * \\
\star * * \\
* * * \\
\star * \star \\
\end{array}$ & $\begin{array}{l}0.082 \\
0.336 \\
0.146 \\
0.070 \\
\end{array}$ & $\begin{array}{l}-0.040 \\
-0.019 \\
0.018 \\
0.045\end{array}$ & $\begin{array}{c}* * * \\
* * * \\
* * * \\
* \star *\end{array}$ & $\begin{array}{l}0.038 \\
0.241 \\
0.245 \\
0.088 \\
\end{array}$ & $\begin{array}{c}-0.006 \\
0.023 \\
\\
-0.001 \\
0.047 \\
\end{array}$ & *** & $\begin{array}{l}0.008 \\
0.147 \\
\\
0.265 \\
0.144 \\
\end{array}$ \\
\hline \begin{tabular}{|l|} 
City/Town Location \\
resides in a city
\end{tabular} & & & & 0.038 & $* * \star$ & 0.414 & 0.000 & & 0.597 \\
\hline $\begin{array}{l}\text { Muslim Effect } \\
\text { belongs to Muslim ethnic group }(0-1) \\
\% \text { of Muslims in prefectural population }\end{array}$ & $\begin{array}{l}-0.021 \\
-0.001 \\
\end{array}$ & $\begin{array}{l}* * * \\
* * * \\
\end{array}$ & $\begin{array}{l}0.017 \\
1.600 \\
\end{array}$ & $\begin{array}{l}-0.037 \\
0.000 \\
\end{array}$ & $* * *$ & $\begin{array}{l}0.014 \\
1.380 \\
\end{array}$ & $\begin{array}{l}-0.052 \\
-0.032 \\
\end{array}$ & $* * *$ & $\begin{array}{l}0.013 \\
0.012 \\
\end{array}$ \\
\hline $\begin{array}{l}\text { Other Prefectural Variables } \\
\text { prefectural unemployment rate } \\
\text { prefectural infant sex ratio } \\
\text { prefectural sex difference in illiteracy rate }\end{array}$ & $\begin{array}{l}-0.020 \\
0.035 \\
0.001\end{array}$ & $\begin{array}{l}* * * \\
\star * \star * \\
* * \star\end{array}$ & $\begin{array}{c}1.590 \\
1.083 \\
20.402\end{array}$ & $\begin{array}{l}-0.019 \\
0.116 \\
0.002 \\
\end{array}$ & $\begin{array}{l}* \star \star \\
* * \star \\
* * \star\end{array}$ & $\begin{array}{c}1.246 \\
1.119 \\
16.157\end{array}$ & $\begin{array}{c}-0.011 \\
-0.008 \\
0.002 \\
\end{array}$ & $\begin{array}{c}* * * \\
* \\
* * *\end{array}$ & $\begin{array}{r}4.631 \\
1.233 \\
10.402 \\
\end{array}$ \\
\hline $\begin{array}{l}\text { Provincial Income Variables } \\
\text { provincial urban real per capita income (100 yuan) } \\
\text { provincial urban real per capita income squared } \\
\text { provincial annual real GDP growth rate over previous } 5 \text { years }\end{array}$ & $\begin{array}{r}-0.001 \\
0.000 \\
0.009\end{array}$ & $\begin{array}{l}* * * \\
* * * \\
\end{array}$ & $\begin{array}{c}18.933 \\
382.2 \\
9.144\end{array}$ & $\begin{array}{r}0.012 \\
0.000 \\
-0.007\end{array}$ & $\begin{array}{l}* * \star \\
* * \star \\
* * \star\end{array}$ & $\begin{array}{c}29.193 \\
902.7 \\
5.948\end{array}$ & $\begin{array}{l}0.004 \\
0.000 \\
0.006\end{array}$ & $\begin{array}{l}* \star * \\
* \star * \\
* * *\end{array}$ & $\begin{array}{r}64.404 \\
4456.3 \\
9.092\end{array}$ \\
\hline $\begin{array}{l}\text { observed P } \\
\text { predicted P }\end{array}$ & $\begin{array}{l}0.867 \\
0.908\end{array}$ & & & $\begin{array}{l}0.870 \\
0.906\end{array}$ & & & $\begin{array}{l}0.773 \\
0.796\end{array}$ & & \\
\hline $\begin{array}{l}\text { Number of obs } \\
\text { LR chi2(22) } \\
\text { Prob > chi2 } \\
\text { Pseudo R2 } \\
\text { Log likelihood }\end{array}$ & $\begin{array}{c}188,031 \\
25,641 \\
0.000 \\
0.174 \\
-60,733\end{array}$ & & & $\begin{array}{c}213,913 \\
23,778 \\
0.000 \\
0.144 \\
-70,820\end{array}$ & & & $\begin{array}{c}62,712 \\
5,330 \\
0.000 \\
0.079 \\
-30,916\end{array}$ & & \\
\hline
\end{tabular}




\begin{tabular}{|c|c|c|c|c|c|c|c|c|c|c|c|c|}
\hline \multirow[b]{4}{*}{ Explanatory Variables } & \multicolumn{12}{|c|}{$\begin{array}{l}\text { Table } 5 \\
\text { rminants of Labor Force Participation } \\
\text { and Non-Migrant Women, Aged } 25-50 \text { in } 1990 \text { \& } 2000\end{array}$} \\
\hline & \multicolumn{6}{|c|}{ Rural Migrants } & \multicolumn{6}{|c|}{ Non-Migrants } \\
\hline & \multicolumn{3}{|c|}{1990} & \multicolumn{3}{|c|}{2000} & \multicolumn{3}{|c|}{1990} & \multicolumn{3}{|c|}{2000} \\
\hline & $\mathrm{dF} / \mathrm{dx}$ & Sig. & $x$-bar & $\mathrm{dF} / \mathrm{dx}$ & Sig. & x-bar & $\mathrm{dF} / \mathrm{dx}$ & Sig. & $\mathrm{x}$-bar & $\mathrm{dF} / \mathrm{dx}$ & Sig & $x$-bar \\
\hline $\begin{array}{l}\text { Co-Residencies } \\
\text { co-resident with parents/parents in-law } \\
\text { co-resident with person aged } 75 \text { or above } \\
\text { co-resident with a disabled person aged less than } 65 \\
\text { number of adults in the household }\end{array}$ & $\begin{array}{l}0.037 \\
0.007 \\
-0.068 \\
0.010\end{array}$ & ** & $\begin{array}{l}0.134 \\
0.024 \\
0.006 \\
2.534\end{array}$ & $\begin{array}{r}0.072 \\
0.010 \\
-0.051 \\
-0.008\end{array}$ & *** & $\begin{array}{l}0.094 \\
0.015 \\
0.009 \\
2.366\end{array}$ & $\begin{array}{l}0.026 \\
0.003 \\
-0.059 \\
-0.007\end{array}$ & $\begin{array}{c}* * \star \\
\star * * \\
* * \star\end{array}$ & $\begin{array}{l}0.180 \\
0.040 \\
0.008 \\
2.659\end{array}$ & $\begin{array}{l}0.046 \\
0.020 \\
-0.075 \\
0.002\end{array}$ & $\mid \begin{array}{c}* * * \\
* * \\
* * *\end{array}$ & $\begin{array}{l}0.192 \\
0.040 \\
0.013 \\
2.575\end{array}$ \\
\hline $\begin{array}{l}\text { Childcare } \\
\text { no children in household, woman age }<=39 \\
\text { youngest co-resident child aged } 0 \text { to } 5 \\
\text { base case: youngest co-resident child aged } 6 \text { to } 12 \\
\text { youngest co-resident child aged } 13 \text { to } 15 \\
\text { youngest co-resident child aged } 16 \text { to } 17 \\
\text { no children in household, woman age }>=40\end{array}$ & $\begin{array}{r}0.118 \\
-0.090 \\
0.019 \\
0.044 \\
0.009 \\
\end{array}$ & $\begin{array}{l}* * * \\
* * *\end{array}$ & $\begin{array}{l}0.087 \\
0.466 \\
0.079 \\
0.033 \\
0.053 \\
\end{array}$ & $\begin{array}{l}0.136 \\
-0.079 \\
0.033 \\
0.085 \\
0.011 \\
\end{array}$ & $* * *$ & $\begin{array}{l}0.216 \\
0.290 \\
0.070 \\
0.034 \\
0.108 \\
\end{array}$ & $\begin{array}{l}0.002 \\
-0.035 \\
-0.005 \\
-0.006 \\
-0.030 \\
\end{array}$ & $\begin{array}{c}* * \\
* * \\
* * * \\
\end{array}$ & $\begin{array}{l}0.040 \\
0.346 \\
\\
0.107 \\
0.058 \\
0.093 \\
\end{array}$ & $\begin{array}{l}-0.006 \\
-0.042 \\
0.005 \\
-0.002 \\
-0.056 \\
\end{array}$ & $* * *$ & $\begin{array}{l}0.042 \\
0.208 \\
\\
0.131 \\
0.065 \\
0.206 \\
\end{array}$ \\
\hline $\begin{array}{l}\text { Education Level } \\
\text { illiterate } \\
\text { primary } \\
\text { base case: junior middle } \\
\text { senior middle } \\
\text { post secondary }\end{array}$ & $\begin{array}{c}-0.093 \\
0.007 \\
0.032\end{array}$ & ** & $\begin{array}{l}0.193 \\
0.347 \\
0.113\end{array}$ & $\begin{array}{l}-0.070 \\
-0.040 \\
0.072\end{array}$ & $\begin{array}{l}* * * \\
* * * \\
* * *\end{array}$ & $\begin{array}{l}0.080 \\
0.340 \\
0.087\end{array}$ & $\begin{array}{l}-0.094 \\
-0.057 \\
0.063 \\
0.092\end{array}$ & $\begin{array}{l}* * * \\
* * * \\
\end{array}$ & $\begin{array}{l}0.117 \\
0.282 \\
0.228 \\
0.036\end{array}$ & $\begin{array}{c}-0.026 \\
0.008 \\
0.089 \\
0.203\end{array}$ & $\begin{array}{l}* * * \\
* * * \\
\end{array}$ & $\begin{array}{l}0.032 \\
0.205 \\
0.251 \\
0.085\end{array}$ \\
\hline $\begin{array}{l}\text { Age Categories } \\
\text { base case: age } 25-29 \\
\text { age } 30-34 \\
\text { age } 35-39 \\
\text { age } 40-44 \\
\text { age } 45-50\end{array}$ & $\begin{array}{c}0.052 \\
0.043 \\
0.018 \\
-0.096\end{array}$ & $\begin{array}{l}* * * \\
* * * \\
* * * \\
\end{array}$ & $\begin{array}{l}0.219 \\
0.206 \\
0.130 \\
0.071 \\
\end{array}$ & $\begin{array}{c}0.002 \\
-0.012 \\
-0.055 \\
-0.137 \\
\end{array}$ & $\begin{array}{c}* * \\
* * * \\
\end{array}$ & $\begin{array}{l}0.292 \\
0.188 \\
0.094 \\
0.101 \\
\end{array}$ & $\begin{array}{c}0.008 \\
0.012 \\
-0.011 \\
-0.110 \\
\end{array}$ & $\begin{array}{l}* * * \\
* * * \\
* * * \\
* * *\end{array}$ & $\begin{array}{l}0.230 \\
0.229 \\
0.159 \\
0.142 \\
\end{array}$ & $\begin{array}{c}0.016 \\
0.018 \\
-0.006 \\
-0.127 \\
\end{array}$ & $\begin{array}{l}* * * \\
* * * \\
* * *\end{array}$ & $\begin{array}{l}0.221 \\
0.222 \\
0.184 \\
0.207 \\
\end{array}$ \\
\hline $\begin{array}{l}\text { Spouse's Education } \\
\text { spouse illiterate } \\
\text { spouse primary } \\
\text { base case: spouse junior middle } \\
\text { spouse senior middle }{ }^{a} \\
\text { spouse post secondary }\end{array}$ & $\begin{array}{c}-0.022 \\
0.022\end{array}$ & ** & $\begin{array}{l}0.370 \\
0.178\end{array}$ & $\begin{array}{r}0.000 \\
-0.046\end{array}$ & $* \star \star$ & $\begin{array}{l}0.245 \\
0.194\end{array}$ & $\begin{array}{l}-0.043 \\
-0.020 \\
0.018 \\
0.045 \\
\end{array}$ & $\begin{array}{c}* * * \\
* * * \\
\end{array}$ & $\begin{array}{l}0.038 \\
0.241 \\
0.245 \\
0.088\end{array}$ & $\begin{array}{l}-0.007 \\
0.022 \\
0.000 \\
0.046 \\
\end{array}$ & $\begin{array}{l}* * * \\
* * *\end{array}$ & $\begin{array}{l}0.008 \\
0.147 \\
0.265 \\
0.144 \\
\end{array}$ \\
\hline $\begin{array}{l}\text { City/Town Location } \\
\text { resides in a city }\end{array}$ & -0.028 & $* * *$ & 0.675 & 0.019 & & 0.691 & 0.038 & $* * *$ & 0.414 & 0.001 & & 0.597 \\
\hline $\begin{array}{l}\text { Muslim Effect } \\
\text { belongs to Muslim ethnic group }(0-1) \\
\% \text { of Muslims in prefectural population }\end{array}$ & $\begin{array}{l}-0.031 \\
0.003\end{array}$ & $\star \star \star \star$ & $\begin{array}{l}0.009 \\
1.728\end{array}$ & $\begin{array}{l}-0.037 \\
-0.022\end{array}$ & & $\begin{array}{l}0.012 \\
0.016\end{array}$ & $\begin{array}{l}-0.038 \\
0.000\end{array}$ & $\begin{array}{c}* * * \\
*\end{array}$ & $\begin{array}{l}0.014 \\
1.380\end{array}$ & $\begin{array}{l}-0.052 \\
-0.046\end{array}$ & $* * *$ & $\begin{array}{l}0.014 \\
0.013\end{array}$ \\
\hline $\begin{array}{l}\text { Other Prefectural Variables } \\
\text { prefectural unemployment rate } \\
\text { prefectural infant sex ratio } \\
\text { prefectural sex difference in illiteracy rate }\end{array}$ & $\begin{array}{l}-0.053 \\
-0.053 \\
0.069 \\
0.000\end{array}$ & $\begin{array}{c}* * * \\
*\end{array}$ & $\begin{array}{c}1.785 \\
1.117 \\
15.274\end{array}$ & $\begin{array}{l}-0.008 \\
-0.038 \\
0.002\end{array}$ & $* * *$ & $\begin{array}{c}4.813 \\
1.212 \\
10.061\end{array}$ & $\begin{array}{l}-0.019 \\
0.115 \\
0.002\end{array}$ & $\begin{array}{c}* * * \\
* * * \\
* * * \\
\end{array}$ & $\begin{array}{c}1.246 \\
1.119 \\
16.157\end{array}$ & $\begin{array}{l}-0.011 \\
-0.008 \\
0.002\end{array}$ & $\begin{array}{c}* * * \\
* \\
* * *\end{array}$ & $\begin{array}{c}4.624 \\
1.233 \\
10.419\end{array}$ \\
\hline $\begin{array}{l}\text { Provincial Income Variables } \\
\text { provincial urban real per capita income (100 yuan) } \\
\text { provincial urban real per capita income squared } \\
\text { provincial annual real GDP growth rate over previous } 5 \text { years }\end{array}$ & $\begin{array}{l}0.056 \\
-0.001 \\
-0.011\end{array}$ & $\begin{array}{c}* * \star \\
* * \star \\
* * \star\end{array}$ & $\begin{array}{l}30.004 \\
958.1 \\
6.253\end{array}$ & $\begin{array}{l}0.020 \\
0.000 \\
0.009\end{array}$ & $\begin{array}{c}* * * \\
* * * \\
* *\end{array}$ & $\begin{array}{c}69.458 \\
5241.5 \\
9.013\end{array}$ & $\begin{array}{l}0.012 \\
0.000 \\
-0.007\end{array}$ & $\begin{array}{c}* * * \\
* * * \\
* * \star\end{array}$ & $\begin{array}{l}29.193 \\
902.7 \\
5.948\end{array}$ & $\begin{array}{l}0.004 \\
0.000 \\
0.007\end{array}$ & $\begin{array}{c}* * * \\
* * * \\
* * *\end{array}$ & $\begin{array}{c}64.395 \\
4454.7 \\
9.090\end{array}$ \\
\hline $\begin{array}{l}\text { observed P } \\
\text { predicted P }\end{array}$ & $\begin{array}{l}0.504 \\
0.503\end{array}$ & & & $\begin{array}{l}0.623 \\
0.631\end{array}$ & & & $\begin{array}{l}0.870 \\
0.906\end{array}$ & & & $\begin{array}{l}0.773 \\
0.796 \\
\end{array}$ & & \\
\hline $\begin{array}{l}\text { Number of obs } \\
\text { LR chi2(22) } \\
\text { Prob > chi2 } \\
\text { Pseudo R2 } \\
\text { Log likelihood }\end{array}$ & $\begin{array}{c}12,479 \\
1,095 \\
0.000 \\
0.063 \\
-8,102\end{array}$ & & & $\begin{array}{c}8,929 \\
619 \\
0.000 \\
0.052 \\
-5,605\end{array}$ & & & $\begin{array}{c}213,915 \\
24,005 \\
0.000 \\
0.145 \\
-70,707\end{array}$ & & & $\begin{array}{c}62,846 \\
5,382 \\
0.000 \\
0.080 \\
-30,972\end{array}$ & & \\
\hline
\end{tabular}

Data Sources: $1 \%$ Micro Sample of the 1990 Population Census of China and the $0.095 \%$ Micro Sample of the 2000 Population Census of China

Significance Levels: ${ }^{* * *}$ significant at $1 \%$; ** significant at $5 \%$; * significant at $10 \%$

${ }^{a}$ for migrants, educational attainment of senior middle school and above

${ }^{\mathrm{b}}$ for migrants, educational attainment of primary school or less 


\section{Table 6 \\ Marginal Effects of the Determinants of Labor Force Participation \\ Urban, Enumerated, Married, Rural-Migrant and Non-Migrant Women, Aged 25-50 in 1990 \& 2000 (Using predicted values of co-residency with parents/in-laws, elders, young children)}

\begin{tabular}{|c|c|c|c|c|c|c|c|c|c|c|c|c|}
\hline \multirow[b]{3}{*}{ Explanatory Variables } & \multicolumn{6}{|c|}{ Rural Migrants } & \multicolumn{6}{|c|}{ Non-Migrants } \\
\hline & \multicolumn{3}{|c|}{1990} & \multicolumn{3}{|c|}{2000} & \multicolumn{3}{|c|}{1990} & \multicolumn{3}{|c|}{2000} \\
\hline & $\mathrm{dF} / \mathrm{dx}$ & Sig. & x-bar & $\mathrm{dF} / \mathrm{dx}$ & Sig. & x-bar & $\mathrm{dF} / \mathrm{dx}$ & Sig. & $\mathrm{x}$-bar & $\mathrm{dF} / \mathrm{dx}$ & Sig. & x-bar \\
\hline $\begin{array}{l}\text { Co-Residencies } \\
\text { predicted: co-resident with parents/parents in-law } \\
\text { predicted: co-resident with person aged } 75 \text { or above } \\
\text { co-resident with a disabled person aged less than } 65 \\
\text { number of adults in the household }\end{array}$ & $\begin{array}{l}0.197 \\
-0.149 \\
-0.115 \\
-0.020\end{array}$ & $* * *$ & $\begin{array}{l}0.127 \\
0.024 \\
0.006 \\
2.534\end{array}$ & $\begin{array}{l}0.191 \\
0.147 \\
-0.054 \\
-0.034\end{array}$ & *** & $\begin{array}{l}0.088 \\
0.015 \\
0.009 \\
2.366 \\
\end{array}$ & $\begin{array}{r}0.086 \\
0.028 \\
-0.071 \\
-0.025\end{array}$ & \begin{tabular}{c|}
$* * \star$ \\
$*$ \\
$* * *$ \\
$* * *$ \\
\end{tabular} & $\begin{array}{l}0.174 \\
0.039 \\
0.008 \\
2.659\end{array}$ & $\begin{array}{c}0.115 \\
0.126 \\
-0.079 \\
-0.028 \\
\end{array}$ & $\begin{array}{l}* * * \\
* * * \\
* * * \\
* * *\end{array}$ & $\begin{array}{l}0.186 \\
0.040 \\
0.013 \\
2.576\end{array}$ \\
\hline $\begin{array}{l}\text { Childcare } \\
\text { no children in household, woman age }<=39 \\
\text { predicted: youngest co-resident child aged } 0 \text { to } 5 \\
\text { base case: youngest co-resident child aged } 6 \text { to } 12 \\
\text { youngest co-resident child aged } 13 \text { to } 15 \\
\text { youngest co-resident child aged } 16 \text { to } 17 \\
\text { no children in household, woman age }>=40\end{array}$ & $\begin{array}{c}0.180 \\
-0.028 \\
0.045 \\
0.072 \\
0.039 \\
\end{array}$ & $\begin{array}{c}* * \\
* * *\end{array}$ & $\begin{array}{l}0.087 \\
0.465 \\
0.080 \\
0.033 \\
0.053 \\
\end{array}$ & $\begin{array}{c}0.170 \\
-0.131 \\
0.055 \\
0.102 \\
0.039 \\
\end{array}$ & $\begin{array}{l}* * * \\
* * *\end{array}$ & $\begin{array}{l}0.219 \\
0.286 \\
0.070 \\
0.035 \\
0.109 \\
\end{array}$ & $\begin{array}{c}0.021 \\
-0.030 \\
0.002 \\
0.002 \\
-0.021 \\
\end{array}$ & $\begin{array}{l}* * \star \\
* \star *\end{array}$ & $\begin{array}{l}0.040 \\
0.346 \\
0.107 \\
0.058 \\
0.093 \\
\end{array}$ & $\begin{array}{c}0.015 \\
-0.058 \\
0.009 \\
0.001 \\
-0.050 \\
\end{array}$ & $* * *$ & $\begin{array}{l}0.042 \\
0.208 \\
0.131 \\
0.065 \\
0.206 \\
\end{array}$ \\
\hline $\begin{array}{l}\text { Education Level } \\
\text { illiterate } \\
\text { primary } \\
\text { base case: junior middle } \\
\text { senior middle } \\
\text { post secondary }\end{array}$ & $\begin{array}{c}-0.091 \\
0.010 \\
0.031\end{array}$ & $* * *$ & $\begin{array}{l}0.191 \\
0.348 \\
0.113\end{array}$ & $\begin{array}{l}-0.067 \\
-0.039 \\
0.065\end{array}$ & $\begin{array}{l}* * * \\
* * *\end{array}$ & $\begin{array}{l}0.078 \\
0.340 \\
0.086\end{array}$ & $\begin{array}{l}-0.091 \\
-0.055 \\
0.063 \\
0.092\end{array}$ & $\begin{array}{l}* * \star \\
* * \star\end{array}$ & $\begin{array}{l}0.117 \\
0.282 \\
0.228 \\
0.036\end{array}$ & $\begin{array}{c}-0.016 \\
0.010 \\
0.088 \\
0.203\end{array}$ & $\begin{array}{l}* * * \\
* * *\end{array}$ & $\begin{array}{l}0.032 \\
0.205 \\
0.251 \\
0.085\end{array}$ \\
\hline $\begin{array}{l}\text { Age Categories } \\
\text { base case: age } 25-29 \\
\text { age } 30-34 \\
\text { age } 35-39 \\
\text { age } 40-44 \\
\text { age } 45-50\end{array}$ & $\begin{array}{c}0.081 \\
0.092 \\
0.078 \\
-0.034\end{array}$ & $\begin{array}{c}* * * \\
* * * \\
* *\end{array}$ & $\begin{array}{l}0.219 \\
0.206 \\
0.130 \\
0.071\end{array}$ & $\begin{array}{l}-0.005 \\
-0.038 \\
-0.077 \\
-0.165\end{array}$ & * & $\begin{array}{l}0.291 \\
0.188 \\
0.095 \\
0.102\end{array}$ & $\begin{array}{r}0.010 \\
0.015 \\
-0.001 \\
-0.085\end{array}$ & $\begin{array}{l}* * * \\
* * \star\end{array}$ & $\begin{array}{l}0.230 \\
0.229 \\
0.159 \\
0.142\end{array}$ & $\begin{array}{c}0.012 \\
0.008 \\
-0.010 \\
-0.122 \\
\end{array}$ & $\star * \star$ & $\begin{array}{l}0.221 \\
0.222 \\
0.184 \\
0.207\end{array}$ \\
\hline $\begin{array}{l}\text { Spouse's Education } \\
\text { spouse illiterate } \\
\text { spouse primary } \\
\text { base case: spouse junior middle } \\
\text { spouse senior middle } \\
\text { spouse post secondary }\end{array}$ & $\begin{array}{l}-0.023 \\
0.019\end{array}$ & ** & $\begin{array}{l}0.368 \\
0.179\end{array}$ & $\begin{array}{l}-0.004 \\
-0.050\end{array}$ & $* * *$ & $\begin{array}{l}0.242 \\
0.193\end{array}$ & $\begin{array}{l}-0.040 \\
-0.019 \\
0.018 \\
0.045\end{array}$ & $\begin{array}{l}* * * \\
* * \star\end{array}$ & $\begin{array}{l}0.038 \\
0.241 \\
0.245 \\
0.088\end{array}$ & $\begin{array}{c}-0.006 \\
0.023 \\
-0.001 \\
0.047\end{array}$ & $\star \star \star *$ & $\begin{array}{l}0.008 \\
0.147 \\
0.265 \\
0.144\end{array}$ \\
\hline $\begin{array}{l}\text { City/Town Location } \\
\text { resides in a city }\end{array}$ & -0.025 & ** & 0.676 & 0.022 & * & 0.698 & 0.038 & $* \star \star$ & 0.414 & 0.000 & & 0.597 \\
\hline $\begin{array}{l}\text { Muslim Effect } \\
\text { belongs to Muslim ethnic group }(0-1) \\
\% \text { of Muslims in prefectural population }\end{array}$ & $\begin{array}{c}-0.059 \\
0.003\end{array}$ & $* * *$ & $\begin{array}{l}0.007 \\
1.704\end{array}$ & $\begin{array}{l}-0.016 \\
0.003\end{array}$ & & $\begin{array}{l}0.009 \\
0.014\end{array}$ & $\begin{array}{l}-0.037 \\
0.000\end{array}$ & $* * \star$ & $\begin{array}{l}0.014 \\
1.380 \\
\end{array}$ & $\begin{array}{l}-0.052 \\
-0.032\end{array}$ & $* * *$ & $\begin{array}{l}0.013 \\
0.012\end{array}$ \\
\hline $\begin{array}{l}\text { Other Prefectural Variables } \\
\text { prefectural unemployment rate } \\
\text { prefectural infant sex ratio } \\
\text { prefectural sex difference in illiteracy rate }\end{array}$ & $\begin{array}{r}-0.052 \\
0.084 \\
0.000\end{array}$ & $\begin{array}{c}* * * \\
* *\end{array}$ & $\begin{array}{c}1.783 \\
1.118 \\
15.254\end{array}$ & $\begin{array}{l}-0.009 \\
-0.031 \\
0.002\end{array}$ & $\begin{array}{c}* * * \\
* *\end{array}$ & $\begin{array}{l}4.830 \\
1.217 \\
9.888\end{array}$ & $\begin{array}{l}-0.019 \\
0.116 \\
0.002\end{array}$ & $\begin{array}{l}* \star * \star \\
* * \star \\
* * *\end{array}$ & $\begin{array}{c}1.246 \\
1.119 \\
16.157\end{array}$ & $\begin{array}{c}-0.011 \\
-0.008 \\
0.002\end{array}$ & $\begin{array}{c}* * * \\
\star \\
* * *\end{array}$ & $\begin{array}{c}4.631 \\
1.233 \\
10.402\end{array}$ \\
\hline $\begin{array}{l}\text { Provincial Income Variables } \\
\text { provincial urban real per capita income (100 yuan) } \\
\text { provincial urban real per capita income squared } \\
\text { provincial annual real GDP growth rate over previous } 5 \text { years }\end{array}$ & $\begin{array}{c}0.056 \\
-0.001 \\
-0.011\end{array}$ & $\begin{array}{l}* * * \\
* * * \\
* * *\end{array}$ & $\begin{array}{l}30.04 \\
960.4 \\
6.274\end{array}$ & $\begin{array}{l}0.019 \\
0.000 \\
0.013\end{array}$ & $\begin{array}{l}* * * \\
* * * \\
* * *\end{array}$ & $\begin{array}{c}69.73 \\
5289.3 \\
9.068 \\
\end{array}$ & $\begin{array}{c}0.012 \\
0.000 \\
-0.007\end{array}$ & $\begin{array}{l}* \star \star \\
* \star \star \\
* * \star\end{array}$ & $\begin{array}{l}29.19 \\
902.7 \\
5.948\end{array}$ & $\begin{array}{l}0.004 \\
0.000 \\
0.006\end{array}$ & $\begin{array}{l}* * * \\
* * * \\
* * *\end{array}$ & $\begin{array}{c}64.40 \\
4456.3 \\
9.092\end{array}$ \\
\hline $\begin{array}{l}\text { observed P } \\
\text { predicted P }\end{array}$ & $\begin{array}{l}0.504 \\
0.503\end{array}$ & & & $\begin{array}{l}0.624 \\
0.631\end{array}$ & & & $\begin{array}{l}0.870 \\
0.906\end{array}$ & & & $\begin{array}{l}0.773 \\
0.796\end{array}$ & & \\
\hline $\begin{array}{l}\text { Number of obs } \\
\text { LR chi2(22) } \\
\text { Prob > chi2 } \\
\text { Pseudo R2 } \\
\text { Log likelihood }\end{array}$ & $\begin{array}{c}12,396 \\
1,066 \\
0.000 \\
0.062 \\
-8,059\end{array}$ & & & $\begin{array}{c}8,500 \\
582 \\
0.000 \\
0.052 \\
-5,337\end{array}$ & & & \begin{tabular}{c|}
213,913 \\
23,778 \\
0.000 \\
0.144 \\
$-70,820$ \\
\end{tabular} & & & $\begin{array}{c}62,712 \\
5,330 \\
0.000 \\
0.079 \\
-30,916\end{array}$ & & \\
\hline
\end{tabular}

Data Sources: 1\% Micro Sample of the 1990 Population Census of China and the 0.095\% Micro Sample of the 2000 Population Census of China

Significance Levels: ${ }^{* *}$ significant at $1 \% ;{ }^{* *}$ significant at $5 \% ;{ }^{*}$ significant at $10 \%$

a for migrants, educational attainment of senior middle school and above

${ }^{b}$ for migrants, educational attainment of primary school or less 